\title{
Coniacian and Santonian ammonites from Bornholm, Denmark
}

\author{
WILLIAM JAMES KENNEDY and WALTER KEGEL CHRISTENSEN
}

\begin{abstract}
Kennedy, W. J. \& Christensen, W. K.: Coniacian and Santonian ammonites from Bornholm, Denmark. Bull. geol. Soc. Denmark, vol. 38, pp. 203-226, Copenhagen, February 19th, 1991.

The ammonite faunas from the Arnager Limestone and Bavnodde Greensand Formations of the island of Bornholm, Denmark are described. The Arnager Limestone at its type locality has yielded five species, including the age diagnostic Scaphites (Scaphites) kieslingswaldensis kieslingswaldensis Langenhan \& Grundey, 1891 and Peroniceras tridorsatum (Schlüter, 1867). The Bavnodde Greensand has yielded seven species, including Scaphites, (Scaphites) kieslingswaldensis fischer Riedel, 1931, which first appears in the Lower Santonian elsewhere in Europe. The age of the two formations is discussed. The Arnager Limestone Formation is in part at least Middle Coniacian on ammonite evidence, Lower Coniacian on inoceramid bivalve evidence, while foraminifera suggest that the formation spans most of the Coniacian. The Bavnodde Greensand Formation is referable to the upper Coniacian-Lower Santonian on the basis of ammonites, belemnites, and inoceramid bivalves.
\end{abstract}

W. J. Kennedy, Geological Collections, University Museum, Oxford OX1 3PW, England. W. K. Christensen, Geological Museum, Øster Voldgade 5-7, DK-1350, Denmark. December 4th, 1989.

\section{Introduction}

The ammonites of the Upper Creceous Arnager Limestone and Bavnodde Greensand Formations of the island of Bornholm were monographed by Ravn $(1902,1918,1921,1946)$. In addition to these papers, ammonites were discussed, commented upon and/or used biostratigraphically by Schlüter (1874), Stolley (1897), Ravn (1930), Rosenkrantz (1945), Birkelund (1957), and more recently by Christensen (1985).

The aim of the present paper is to describe the ammonite faunas of the two formations and place them in the international stratigraphic framework on ammonite evidence as well as evidence from other fossil groups. The material includes collections made in the last part of the 19th century and the beginning of this century in addition to collections made recently by WKC in collaboration with German and Danish colleagues.

The Coniacian Arnager Limestone and upper Coniacian-Lower Santonian Bavnodde Greensand Formations are of biostratigraphic importance, because they have yielded ammonites, inoceramids, belemnites, and microfossils. The ammonites are described here, and work is in progress on the inoceramids by Dr. K.-A. Tröger, Freiberg and WKC, belemnites by Dr. M.-G.
Schulz, Kiel and WKC, and microfossils by Professor M. B. Hart and his research group at Plymouth, U.K.

\section{Geological setting}

The island of Bornholm in the Baltic Sea is a horst within the Fennoscandian Border Zone: that is the marginal area between the stable Precambrian Baltic Shield and the subsiding Late Palaeozoic-Mesozoic Danish Subbasin. The northern part of the island consists of Precambrian basement, whereas Palaeozoic and Mesozoic rocks occur in down-faulted blocks to the south and west (Fig. 1).

The marine Cretaceous sediments ranging in: age from Albian to Santonian include the following lithostratigraphic units, from bottom to top: Arnager Greensand, Arnager Limestone, and Bavnodde Greensand Formations. The ammonites of the Arnager Greensand Formation were described by Kennedy, Hancock \& Christensen (1981) and this formation will not be considered further.

The Arnager Limestone and Bavnodde Greensand Formations occur in two fault blocks: the 


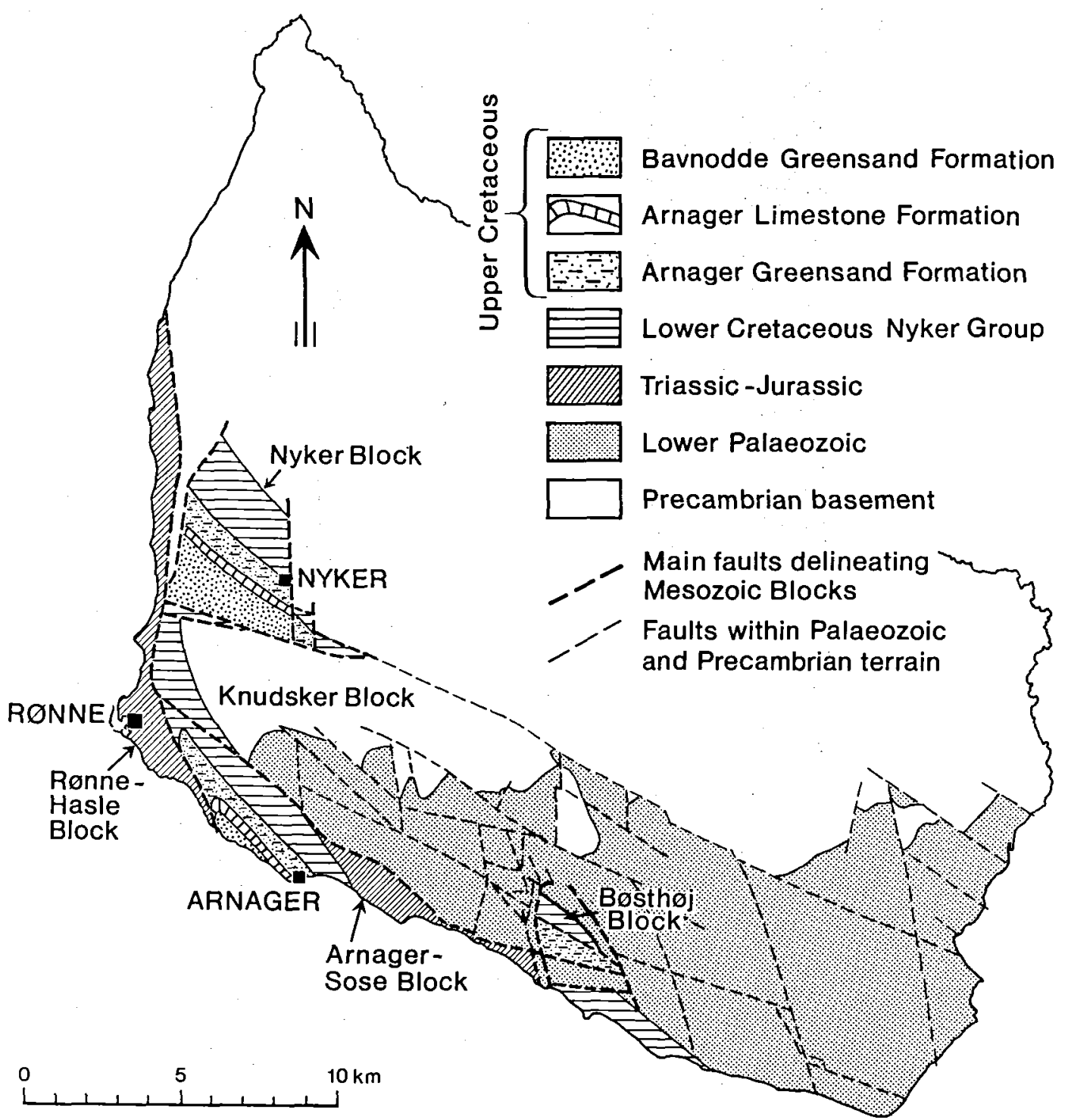

Fig. 1. Geological map of Bornholm. Modified from Gry (1960) and Gravesen et al. (1982).

Nyker block to the west and the Arnager-Sose block to the southwest (Fig. 1) (Ravn 1918, 1921, 1946; Gry, 1960). The names of the fault blocks are from Gravesen et al. (1982).

\section{Arnager Limestone Formation}

This formation is about $12-20 \mathrm{~m}$ thick (Gry 1960). It rests on the Middle Cenomanian Arnager Greensand with an erosional unconformity and is overlain conformably by the Bavnodde Greensand. At the type locality on the southwest coast immediately west of Arnager (Fig. 2), the formation consists of hard, siliceous, marly chalk with a $20 \mathrm{~cm}$ thick basal bed of phosphatized and glauconitized pebbles. The lower seven metres of the strongly bioturbated limestone is light grey and has a carbonate content varying from $45-70 \%$ (Christensen 1985). Noe-Nygaard \& Surlyk (1985) showed that deposition of this part of the formation took place in a complex of low mud-mounds. The top part of the limestone and 
the boundary with the overlying formation is sometimes exposed in the bay east of Horsemyre Odde. Here the formation is bluish-grey and the carbonate content is only $30 \%$ (Christensen 1985).

At the brook Stampe $\AA$ (loc. $4-5$ in Fig. 2) the formation is developed as glauconitic marl and sandy limestone. In the Nyker fault block the formation consists of sandy, glauconitic marl, the so-called 'Glass-marl' of Ravn (1946).

The majority of the ammonites described here were collected from the basal seven metres of the formation at the type locality. A single age diagnostic specimen came from the top part of the formation east of Horsemyre Odde. Ammonites are unknown from the Stampe $\AA$ area and the Nyker fault block.

\section{Bavnodde Greensand Formation}

Gry (1960) estimated the thickness of the formation to be about $180 \mathrm{~m}$. The greensand rests with a disconformity on the Arnager Limestone without any development of conglomerate or phosphatized nodules at the base (Ravn 1921, Christensen 1985). The formation is unconformably overlain by Quaternary glacio-fluvial deposits. The greensand is the youngest pre-Quarternary formation known from Bornholm. Offshore from Bornholm, the formation may be as thick as $\mathbf{8 0 0}$ m (Jensen \& Hamann 1989).

At the type locality on the southwest coast, the formation consists of poorly sorted calcareous glauconitic fine-grained silty quartz sand. Several layers of nodular greensand, quartzitic beds and marly beds are included in the greensand, which is strongly bioturbated. In the Nyker fault block the formation consists of greensands and marls.

On the southwest coast, the formation is known from scattered exposures from west of Bavnodde to east of Horsemyre Odde (Fig. 2). In the Nyker fault block the formation has been recorded from stream cuttings of Blykobbe $\AA$ at the farmhouse Risenholm, and the abandoned Jydegård marl pit (Fig. 3) (Ravn 1946, Gry 1956, Birkelund 1957).

The ammonites described here came from exposures east and west of Bavnodde, at Forchhammers Odde and Horsemyre Odde, in addition to Blykobbe $\AA /$ Risenholm and Jydegård.

\section{Age of the Arnager Limestone and Bavnodde Greensand Formations}

Arnager Limestone Formation. - The biostratigraphical age of this formation has formerly been the subject of much discussion which is summarized by Christensen (1973: 132-133). Ravn $(1918,1930,1946)$ and Birkelund (1957) placed the limestone in the Upper Turonian on the basis of the presumed occurrence of Scaphites geinitzi d'Orbigny, Inoceramus lamarcki Parkinson var. cuvieri Sowerby, and 'Actinocamax' lundgreni Stolley. This conclusion was opposed by Stolley (1930) and Jeletzky (1958). According to Stolley the scaphitids could not be determined safely due to their state of preservation and the inoceramids were incorrectly identified. Stolley placed the Arnager Limestone in the 'Mittlerer Emscher' (= Middle-Upper Coniacian, see Ernst 1968: Table 1) on the basis of inoceramids deterrnined by. $R$. Heinz. Jeletzky (1958) suggested that belemnites occurring in the Turonian elsewhere were not so advanced as those from the Arnager Limestone; he therefore suggested that it was of late Coniacian age.

The Arnager Limestone Formation at its type locality yields numerous Scaphites (Scaphites) kieslingswaldensis kieslingswaldensis Langenhan \& Grundey, 1891, and Yezoites sp., the former ranging from just above the base to the top of the unit. Where well-documented in Germany and France (Kaplan, Kennedy \& Wright 1987) this species first appears in the middle part of the Lower Coniacian, and ranges to the Upper Coniacian. It is unknown in the Lower Santonian and this evidence shows the Arnager Limestone to be wholly within the Coniacian in ammonite terms (e.g. sensu Kennedy 1984, 1985). Peroniceras (Peroniceras) tridorsatum (Schlüter, 1867) is represented by a single individual and demonstrates the presence of the Middle Coniacian tridorsatum Zone (sensu Kennedy 1984, 1985). Fragments of Scalarites recognised are not age diagnostic, while Neocrioceras (Schlueterella) cf. maderi Immel, Klinger \& Wiedmann, 1982, which is represented by four specimens, two from only $2-3 \mathrm{~m}$ above the base of the Arnager Limestone, was previously known only from the Lower Santonian of the Brandenberg Tyrol, Austria.

The Arnager Limestone Formation at its type 


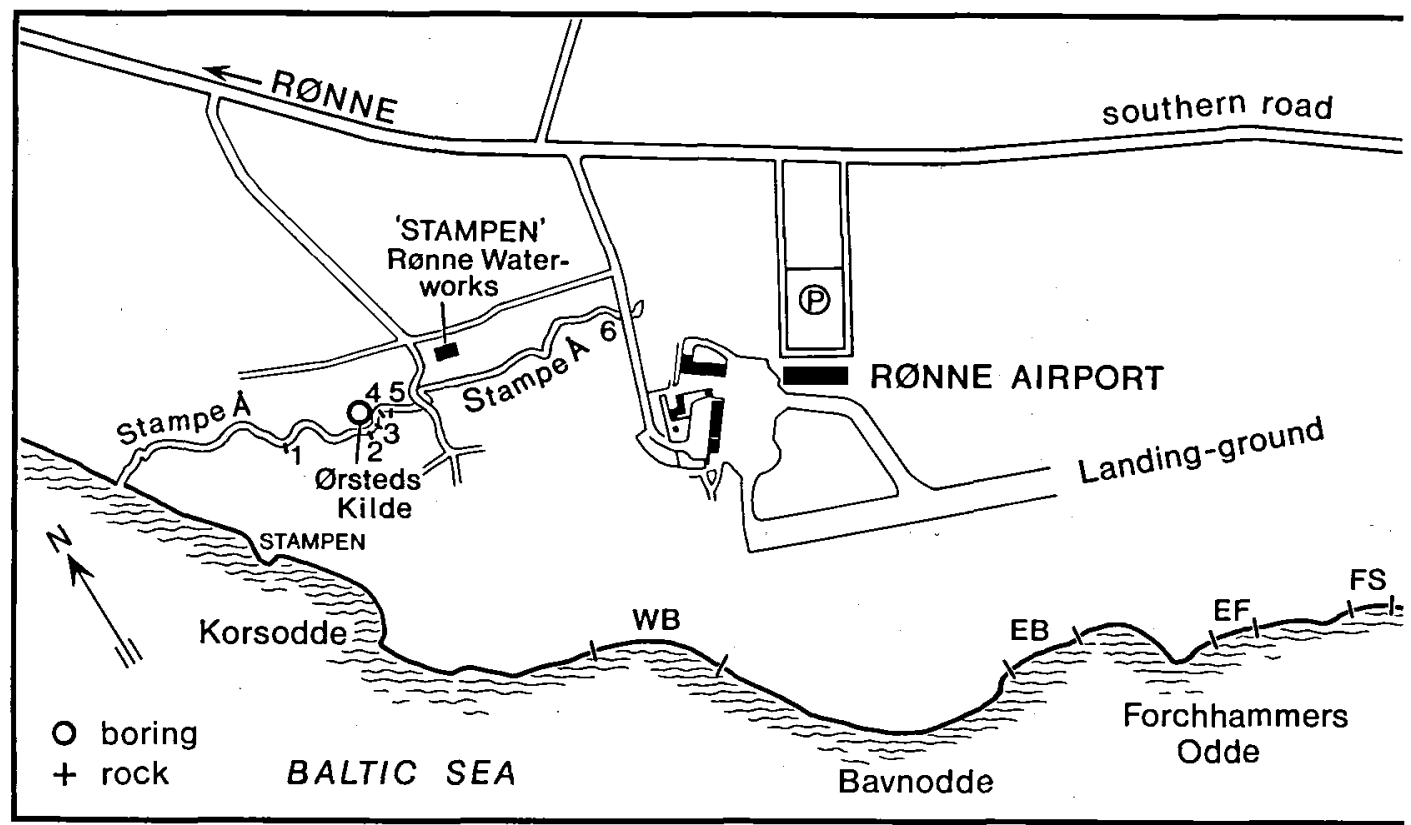

Fig. 2. Map of the Arnager-Sose fault block showing exposures on the southwest coast of Bornholm. The Arnager Limestone Formation is exposed from west of Arnager to east of Horsemyre Odde. The Bavnodde Greensand Formation is exposed from east of Horsemyre Odde to west of Bavnodde. The outcrops showing Bavnodde Greensand on the southwest coast have the following abbreviations: $\mathrm{WB}=$ west of Bavnodde, $\mathrm{EB}=$ east of Bavnodde, $\mathrm{EF}=$ east of the Forchhammers Odde, FS = between Forchhammers Odde and Skidteper, WS $=$ west of Skidteper, and $\mathrm{H}=$ Horsemyre Odde. In the Stampe $\AA$ area the Arnager Limestone Formation is exposed at localities 4 and 5.

locality has yielded a diverse inoceramid fauna which was determined recently by Dr. K.-A. Tröger, Freiberg; a manuscript by Tröger and WKC is in preparation. Following this manuscript the basal seven metres of the formation has yielded the following age diagnostic species: Inoceramus walterdorfensis $\mathrm{cf}$. hannovrensis Heinz, I. lusatiae Andert, $I$. cf. rotundatus Fiege, and $I$. wanderi Andert. These species are elsewhere recorded from the top of the Turonian and the base of the Coniacian. The sum of evidence suggests that the basal seven metres of the limestone at its type locality is Lower Coniacian in inoceramid terms.

The top part of the formation, exposed east of Horsemyre Odde, has yielded $I$. cf. lusatiae and I. cf. guerichi Heinz, two species occurring in the Lower Coniacian.

On the basis of foraminifera, Solakius \& Larson (1985) suggested that the Arnager Limestone at the type locality is of Coniacian age, and they recognised a lower Reussella kelleri Zone of early Coniacian age and an upper Stensioeina exsculpta exsculpta Zone of late Coniacian age.
In summary it can be concluded that the Arnager Limestone Formation at its type locality is Coniacian. There are, however, discrepancies with respect to which part of the Coniacian Stage the formation should be placed. It is Middle Coniacian on ammonite evidence, Lower Coniacian on the basis of inoceramid bivalves, while the foraminifera suggest that the formation spans most of the Coniacian. These discrepanices, however, may be due to differing concepts of the Coniacian Substages.

Bavnodde Greensand Formation. - The Bavnodde Greensand at Bavnodde, Forchhammers Odde, and Risenholm yields numerous Scaphites (S). kieslingswaldensis ficheri Riedel, 1931. Kennedy (1986) erroneously referred to this as an exclusively Campanian species (see also Christensen 1985). It in fact first appears in the Lower Santonian and ranges to the lowest Campanian. The remaining few ammonites: Texanites (Texanites) pseudotexanum (de Grossouvre, 1894) from Bavnodde and Forchhammers Odde, Protexanites (Protexanites) sp. from Risenholm, No- 


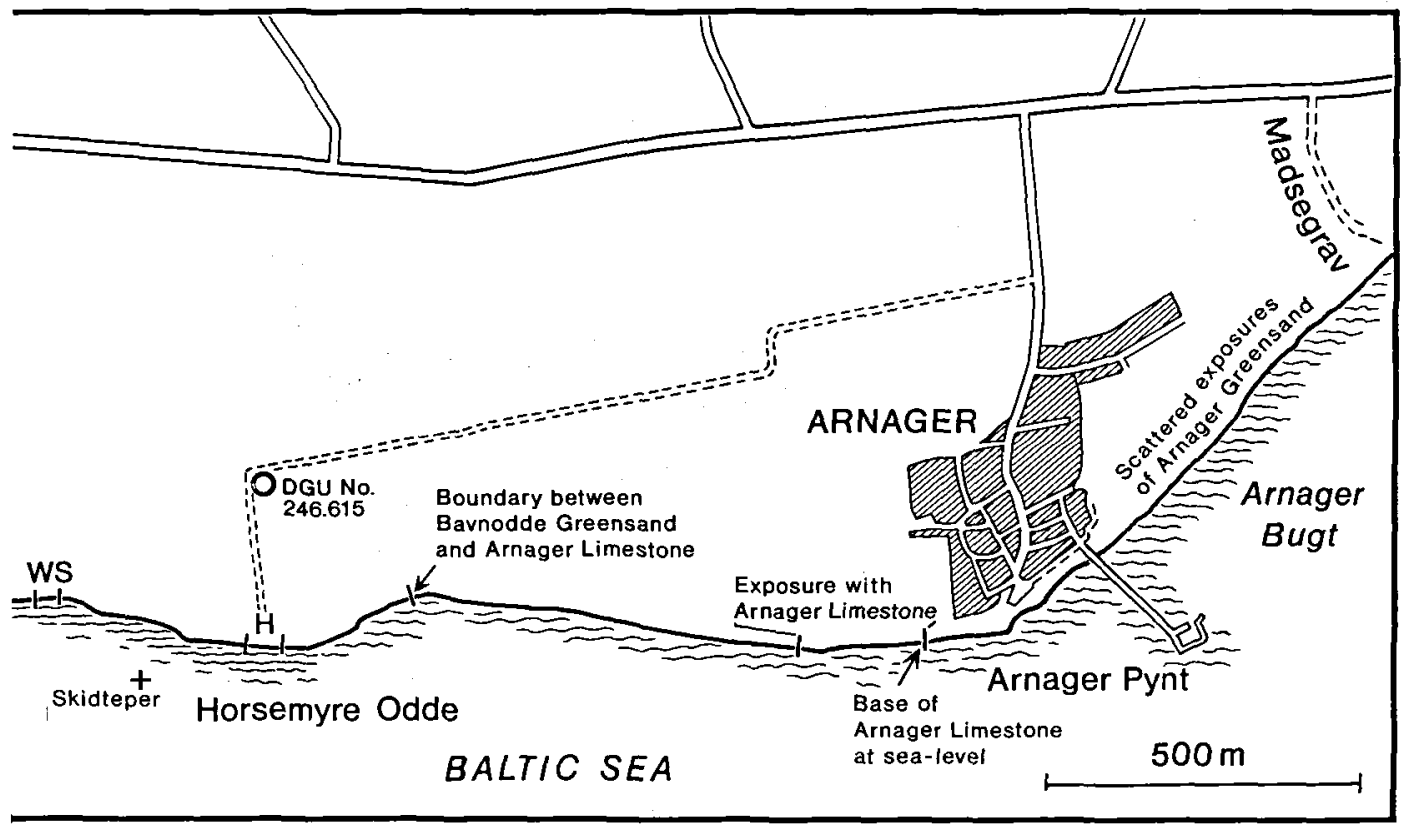

wakites cf. hernensis (Schlüter, 1867) from Bavnodde, Nostoceras (Bostrychoceras) cf. saxonicum (Schlüter, 1876) from Jydegård, Baculites cf. fuchsi Redtenbacher, 1873 from Risenholm; and Baculites cf. incurvatus Dujardin, 1837 from Bavnodde, either indicate a Santonian date, are longer ranging, or are imprecisely dated. $N$. hernensis (Schlüter, 1867) may be Coniacian at its type occurrence in Germany. There is no evidence for any Campanian ammonites.

The greensand was referred to the upper Lower to basal Middle Santonian, upper part of the undulatoplicatus Zone to lower part of the cordiformis/westfalica Zone on belemnite evidence by Christensen (1971). New belemnite collections are being studied by Dr. M.-G. Schulz (Kiel) and WKC, and preliminary studies seem to indicate that the greensand probably embraces the upper Coniacian to Lower Santonian. The greensand that crops out in the bay between Forchhammers Odde and Horsemyre Odde has only yielded 'Actinocamax' lundgreni Stolley and is considered to be late Coniacian. The greensand exposed east and west of Bavnodde, at Horsemyre Odde, and at Jydegård has yielded Gonioteuthis westfalica westfalica (Schlüter) Belenmitella propinqua (Moberg), and 'A' lundgreni and is considered to be Lower Santonian.

Ravn (1921) recorded Inoceramus cordiformis

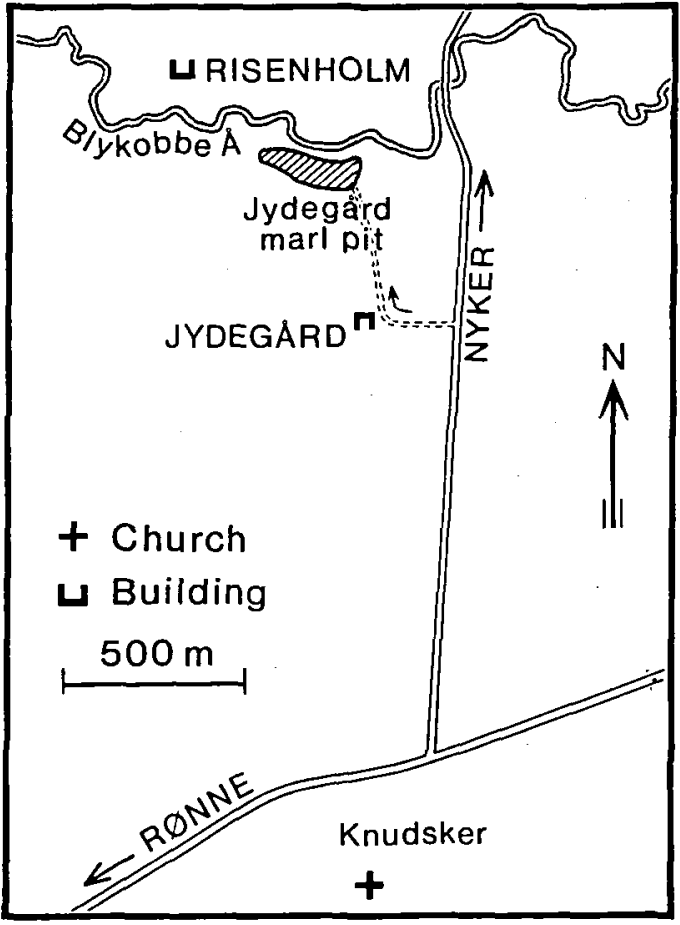

Fig. 3. Map showing the Jydegård marl pit and Blykobbe $\AA$ at Risenholm. The Bavnodde Greensand is recorded from the marl pit and stream cuttings of the Blykobbe $\AA$ close to Risenholm. 


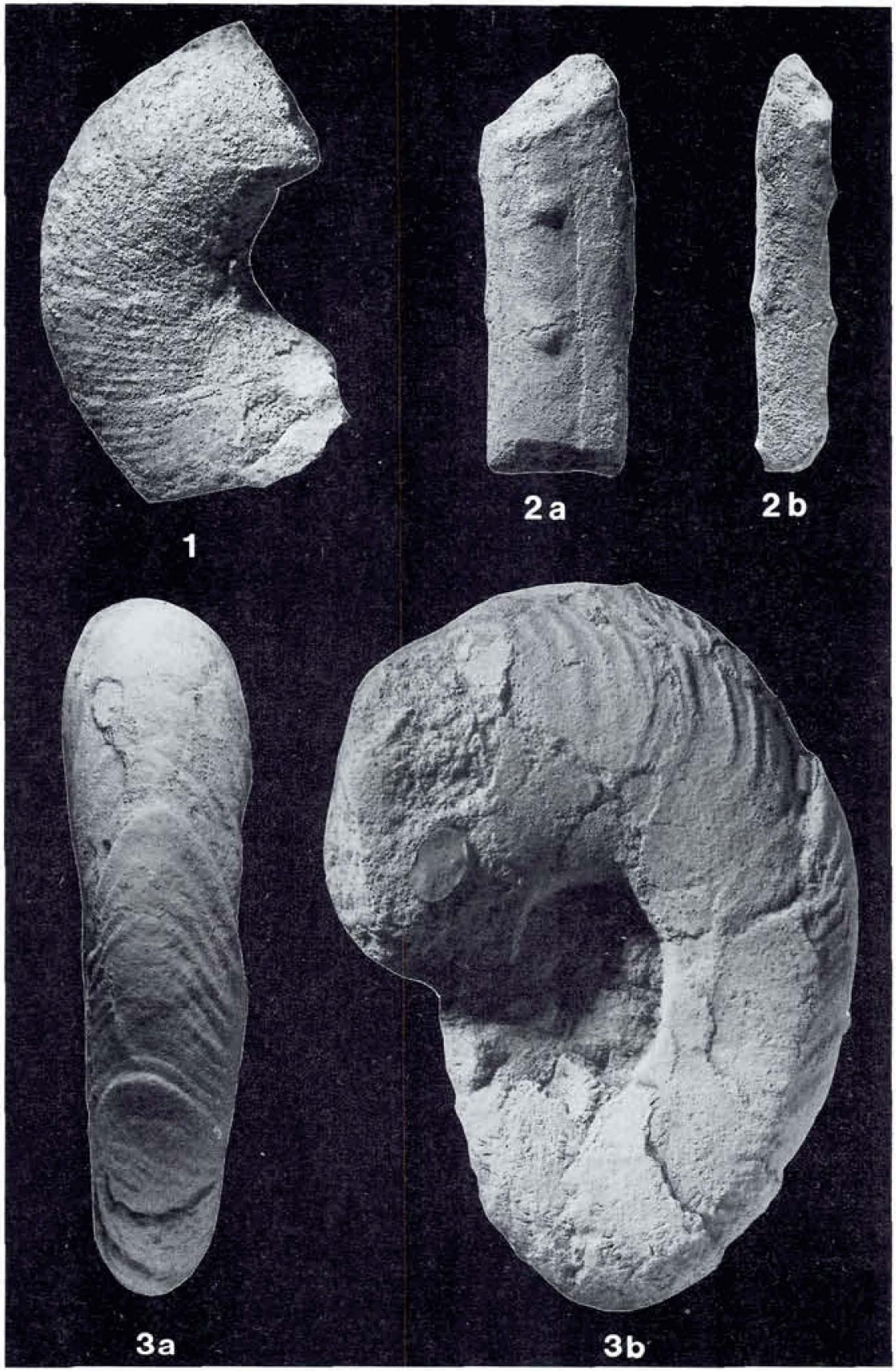

Plate 1:

Fig. 1. Nostoceras (Eubostruchoceras) cf. saxonicum (Schlüter, 1876). MGUH 19697.

Fig. 2. Baculites of incurvatus Dujardin. 1837. MGUH 19705.

Fig. 3. Nowakites of. hernensis (Schlüter, 1867). MGUH 19649 All figures are natural size. 


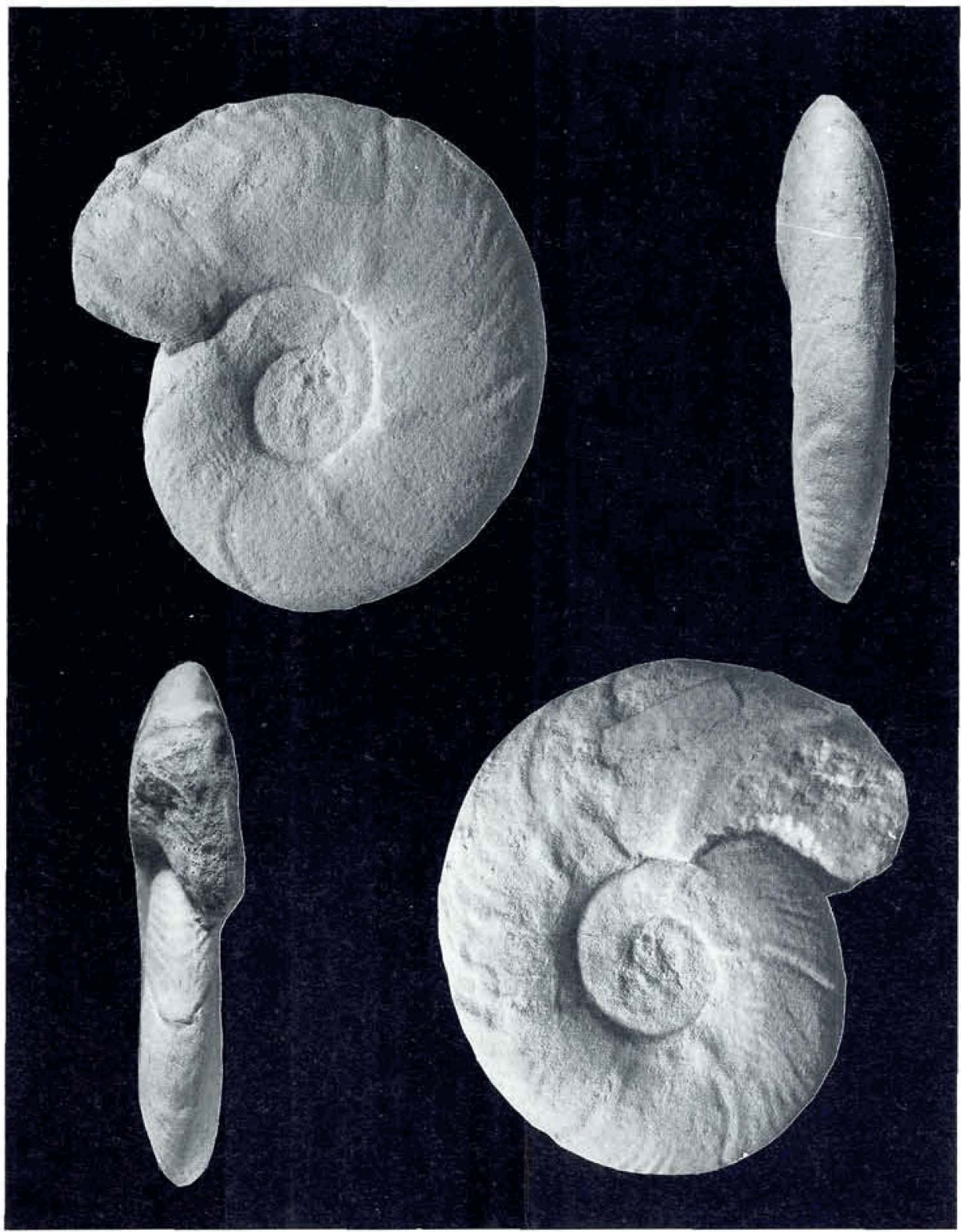

Fig. 4. Nowakites hernensis (Schlüter, 1867). The holotype, by monotypy, no. 27 in the Collections of the Geologisches und Palontologisches Institut, Bonn. From the "grauen Mergeln" of the "Schachtes von der Heydt, Herne, Westphalia", German Federal Republic. Figures are $\times 1$.

Sowerby, and Christensen (1985) recorded $I . p a-$ tootensiformis Seitz and 1. angustus Beyenburg (determined by Professor E. G. Kauffman, Boulder) from the formation. The two last-mentioned species are elsewhere known from the Upper Santonian to Lower Campanian. K.-A. Tröger has revised the inoceramids from the greensand, and following a manuscript by Tröger and WKC, the greensand exposed east and west of Bavnodde is referable to the lower Lower Santonian, the greensand at Jydegård to the basal Santonian and possibly the uppermost Coniacian, and the greensand at Risenholm to the lowest Santonian. It is worthy of note that Tröger has not recog- 
nised $I$. cordiformis, $I$. patootensiformis or $I$. angustus.

In summary it can be concluded that the Bavnodde Greensand Formation ranges from the Upper Coniacian to Lower Santonian. The oldest part of the greensand, exposed in the bay between Forchhammers Odde and Horsemyre Odde, is probably of late Coniacian age. No ammonites and inoceramids are known from this part of the greensand. The greensand at Bavnodde, Forchhammers Odde and Horsemyre Odde on the southwest coast, at Risenholm and Jydegård in the Nyker fault block is Lower Santonian.

\section{Systematic descriptions}

Specimens figured by earlier workers are in the Type Collection of the Geological Museum of the University of Copenhagen, prefix MMH. The specimens figured in the present paper that have not been figured before are filed as MGUH. In addition, specimens that have not been figured carry the accession numbers of the museum with prefix GM.

Order Ammonoidea Zittel, 1884

Suborder Ammonitina Hyatt, 1889

Superfamily Desmocerataceae Zittel, 1895

Family, Pachydiscidae Spath, 1922

Genus Nowakites Spath, 1922

Type species: Pachydiscus carezi de Grossouvre, 1894 , p. 190 , pl. 25 , fig. 3 ; pl. 37 , fig. 5 ; by original designation by Spath (1922, p. 124).

Nowakites cf. hernensis (Schlüter, 1867)

PI. 1, fig. 3a, b; Fig. 4.

Compare:

1867 Ammonites Hernensis Schlüter, p. 35, pl. 6, fig. 4.

non 1872 Ammonites Hernensis Schlüter; Schlüter, p. 40, pl. 11, figs 13, 14 (= Puzosia mulleri de Grossouvre).

1922. Tragodesmoceras hernensis (Schlüter); Spath, p. 128.

1925 Tragodesmoceras hernense Schlüter; Diener, p. 131.

1979 . Nowakites hernensis (Schlüter); Matsumoto, p. 37.
Material: MGUH 19694 collected loose from the Bavnodde Greensand at Bavnodde.

Description: The specimen is crushed and distorted, with a maximum diameter of $87 \mathrm{~mm}$. Coiling seems to have been fairly evolute with the umbilicus of moderate depth and breadth. The whorls expand slowly and seem to have been compressed, with a flattened umbilical wall, narrowly rounded umbilical shoulder, flattened flanks and narrowly rounded venter. There are an estimated four or five constrictions per half whorl. They are narrow and of moderate depth, straight and prorsiradiate on the inner flank but flexed forward and markedly concave on the outer flank (Pl. 1, fig. 3b), crossing the venter in a narrow linguoid projection. Each constriction is preceded by a strong, rounded collar-rib. It is impossible to determine whether they arose at umbilical bullae or not, but they extend across the flanks and strengthen markedly across the ventrolateral shoulders and venter ( $\mathrm{Pl}$. 1, fig. 3a). A much weaker rib follows the constriction, while the spaces between successive constrictions are ornamented by around seven ribs of variable strength that arise both low and high on the flanks, where they are markedly concave, and are strengthed over the venter, where they parallel constrictions and collars.

Discussion: The Bornholm specimen, though distorted, bears a striking resemblance to the holotype (by monotypy) of Schlüter's Ammonites hernensis $(1867$, pl. 6, fig. 4), reillustrated here as Fig. 4, from the "grauen Mergeln" of the Schachtes von der Heydt of Herne, Westphalia. The Bornholm specimen differs, however, in the lack (possibly due to damage) of umbilical bullae that suggest hernensis to be a Nowakites.

Occurrence: Coniacian (?) of Herne, Westphalia; Lower Santonian of Bornholm.

Superfamily Acanthocerataceae de Grossouvre, 1894

Family Collignoniceratidae Wright \& Wright, 1951

Subfamily Peroniceratinae Hyatt, 1900

Genus and Subgenus Peroniceras de Grossouvre, 1894 
Fig. 5. Peroniceras (Peroniceras) tridorsatum (Schlüter, 1867). MGUH 19695, from the Arnager Limestone. Figure is $\times 1$.

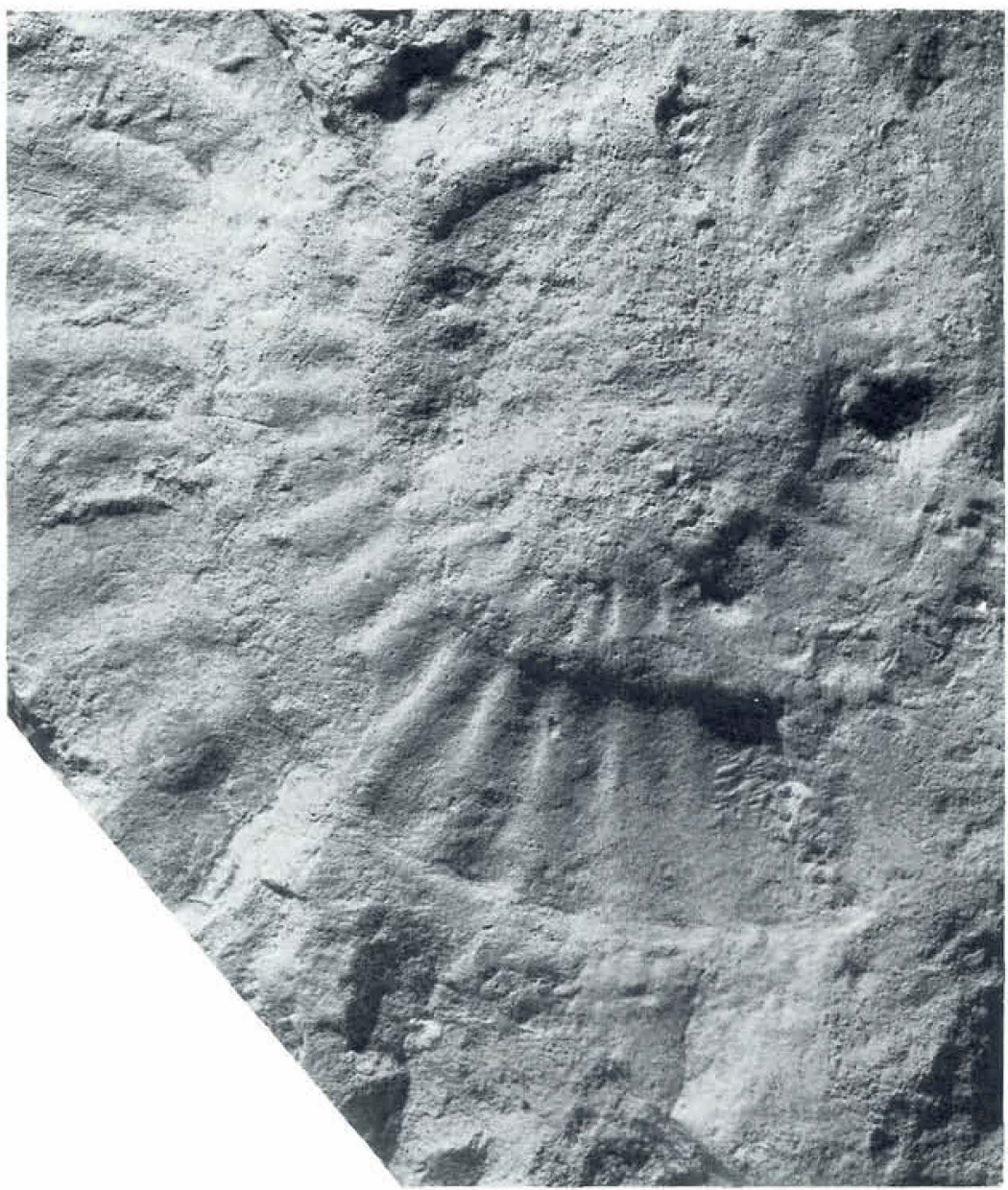

Type species: Peroniceras moureti de Grossouvre, 1894 , p. 100 , pl. 11 , fig. 4 , by original designation; $=$ Ammonites tridorsatus Schlüter, 1867, p. 26, pl. 5, fig. 1.

Peroniceras (Peroniceras) tridorsatum (Schlüter, 1867)

Fig. 5

1867 Ammonites tridorsatus Schlüter, p. 26, pl. 5 , fig. 1 .

1984 Peroniceras (Peroniceras) tridorsatum (Schlüter, 1867); Klinger \& Kennedy, p. 139 figs $3-15,16 \mathrm{D}-\mathrm{E}$ (with full synonymy).

1984 Peroniceras (Peroniceras) tridorsatum
(Schlüter, 1867); Kennedy, p. 62, pl. 11, figs $3-6$; pl. 12 , figs $1-5$; pl. 13 , figs $5-11$; pl. 14, figs 1, 4; text-figs $13 \mathrm{G}, \mathrm{L}, 18 \mathrm{C}-\mathrm{E}$, 19.

1985 Peroniceras (Peroniceras) tridorsatum (Schlüter, 1867); Kennedy, pl. 1, figs 5-7. 1986a Peroniceras (Peroniceras) tridorsatum (Schlüter. 1867); Kennedy, pl. 19, figs 5-7.

Type: The holotype, the original of Schlüter 1867, pl. 5, fig. 1, from the Coniacian of Westphalia in the German Federal Republic, is lost.

Material: MGUH 19695, from the Arnager Limestone, Arnager. 


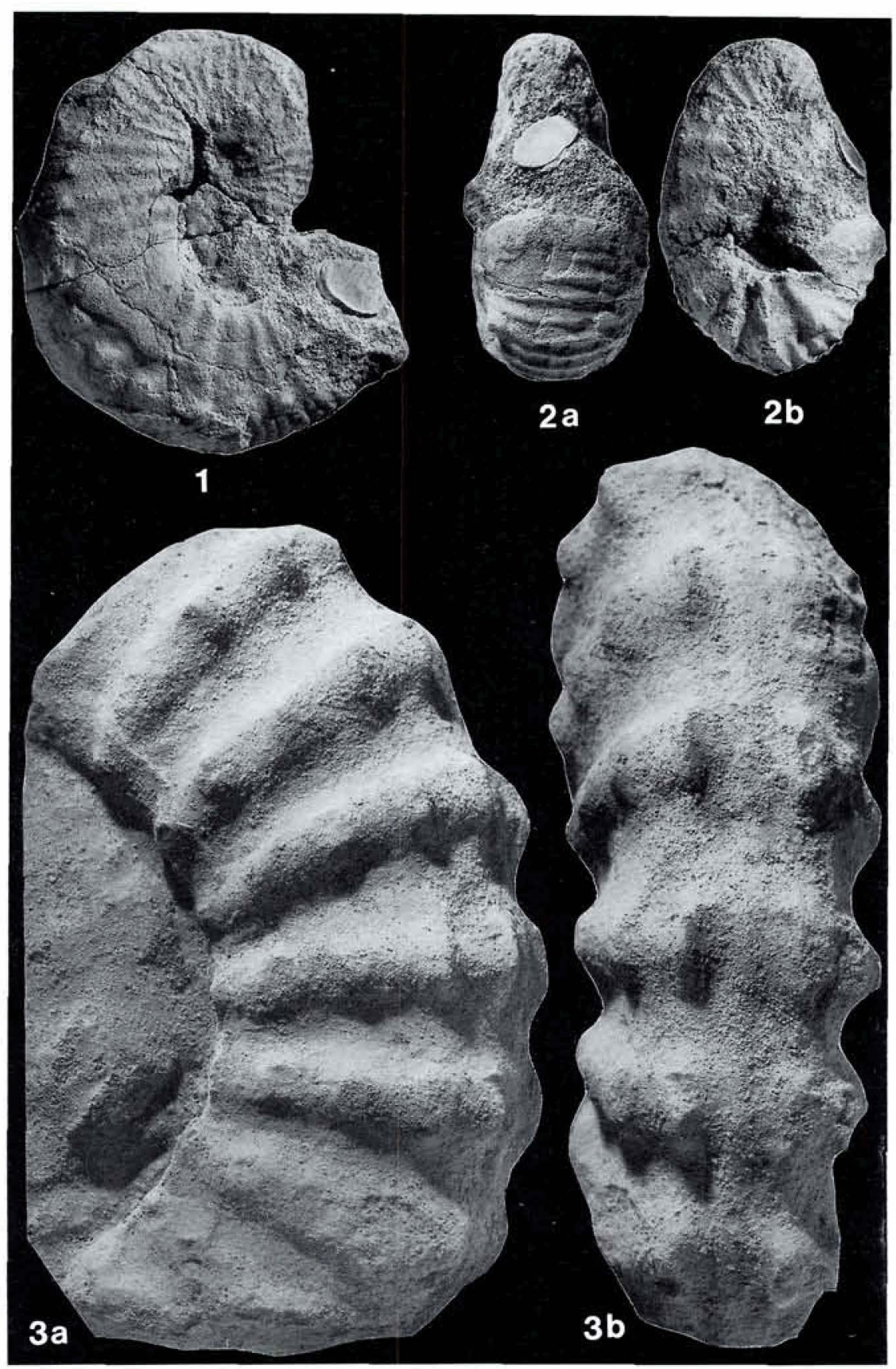

Plate 2:

Figs 1. 2. Scaphites (Scaphites) kieslingwaldensis fischeri Riedel, 1931. 1 is MGHU 19710; 2 is MGHU 19711.

Fig. 3. Texanites (Texanites) pseudotexanum (de Grossouvre, 1894). MMH 5164.

All figures are natural size. 


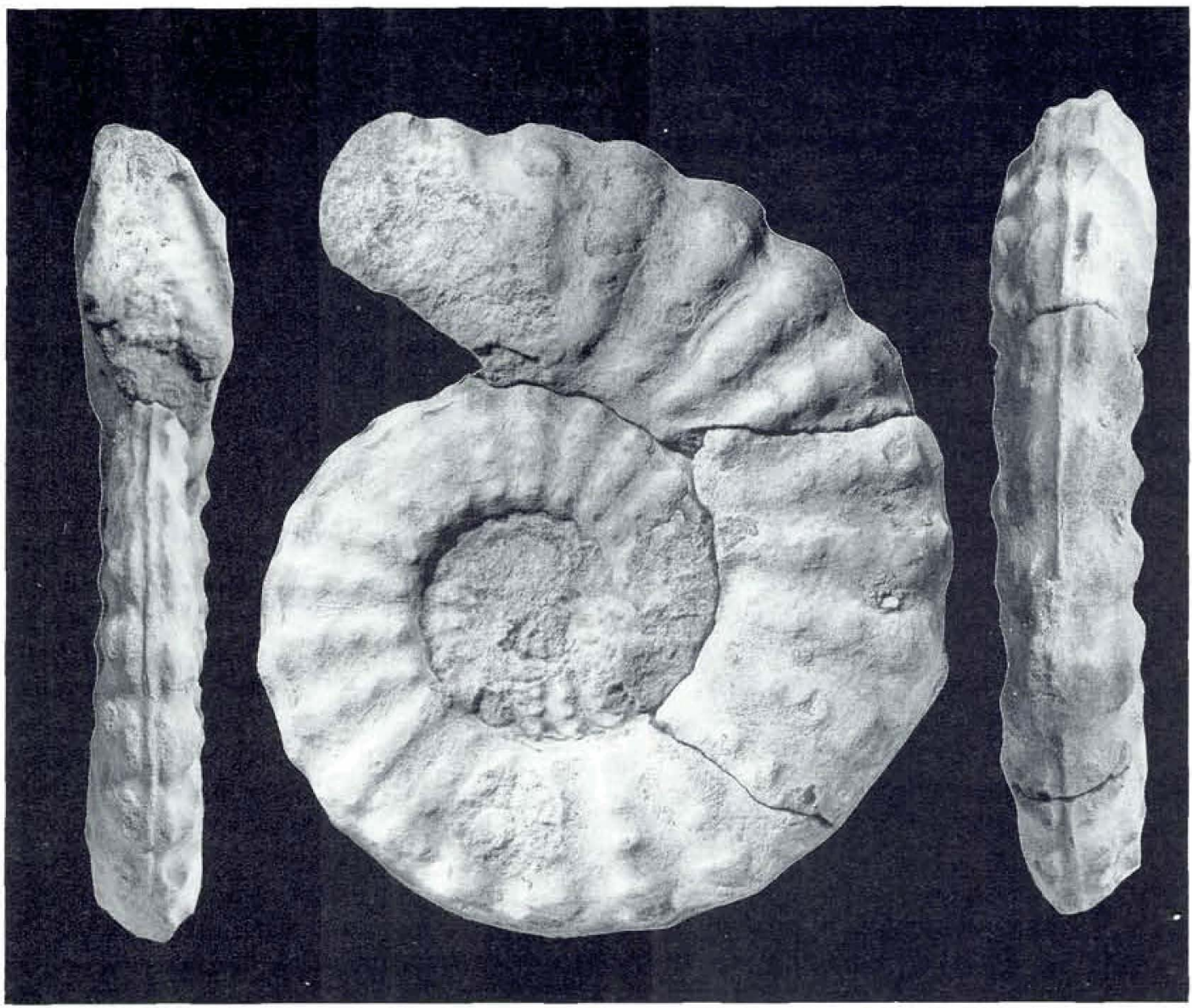

Fig. 6. Texanites (Texanites) pseudotexanum (de Grossouvre, 1894). The lectotype, no, 87 in the Collections of the Geologisches und Paläontologisches Institut. Bonn. From the "Emscher Mergel der Zeche Ewald beitterten in Westfalen" in the German Federal Republic. Reduced $\times 0.63$.

Description: The specimen is a worn external mould of a crushed nucleus $95 \mathrm{~mm}$ in diameter and part of the succeeding whorl, the latter with a maximum whorl height of $42.5 \mathrm{~mm}$. Coiling is very evolute, with $\mathrm{U}=55 \%$ approximately of the diameter. Ornament consists of straight prorsiradiate ribs, all long, arising from feeble umbilical bullae, strengthening and broadening across the outer flank to terminate in prominent ventral clavi. No other features of ornament are visible.

Discussion: The coiling and simple uniform ribs, without secondaries, characterise this specimen and show it to be $P$. (P.) tridorsatum. Of other European species, P. (P.) lepeei (Fallot, 1885) (see Kennedy 1984, p. 68, pl. 11, figs 1, 2; pl. 12, figs 10,11 ; pl. 14, figs 2,3 ; text-fig. 20A) is distinguished by its lack of umbilical bullae and more delicate ribbing; $P$. (P.) subtricarinatum (d'Orbigny, 1850) (see Kennedy 1984, p. 71, pl. 12, figs 6-9; text-fig. 21) has branching and intercalated coarse ribs; $P$. (P.) westphalicum (von Strombeck, 1859) (see Kennedy, 1984, p. 71, pl. 14 , fig. 5 ; pl. 15 , figs $1-3,6-7$ ) has coarser ribs that efface on the outer flank; $P$. $(P$.) dravidicum (Kossmat, 1895) (see Kennedy 1984, p. 78, pl. 15. figs $4-5$; text-figs $3 \mathrm{I}, \mathrm{J}, 18 \mathrm{~F}, 22$ ) has ribs branching from umbilical bullae.

Occurrence: Where precisely dated, this species is confined to, and is the index of, the Middle Coniacian tridorsatum Zone. It is known from the Boulonnais, Touraine, Aquitaine, Dieulefit (Drome), the Beausset Basin (Var) and the Corbières in France, northern Germany, Spain, 
Italy, Roumania, North Africa, Zululand, South Africa, Madagascar, and Texas in the USA.

Subfamily Texanitinae Collignon, 1948

Genus and Subgenus Texanites Spath, 1932, p.379

Type species: Ammonites texanus Roemer, 1852, p. 31, pl. 3, fig. 1; by original designation.

Texanites (Texanites) pseudotexanum (de Grossouvre, 1894)

PI. 2, figs 3a, 3b; Fig. 6

1876 Ammonites Texanus Römer; Schlüter, p. 41 (pars); p. 155, pl. 41, figs 1, 2; non pl. 12, figs 1-3 (= Paratexanites desmondi (de Grossouvre, 1894)); non pl. 42, fig. 11 (= Texanites sp. indet.).

1894 Mortoniceras pseudotexanum de Grossouvre, p. 84.

?1906 Mortoniceras pseudotexanum de Grossouvre; Wollemann, p. 379.

?1916 Mortoniceras pseudotexanum de Grossouvre; Stolley, p. 84.

1925 Mortoniceras pseudotexanum Grossouvre; Diener, p. 147.

1934 Mortoniceras pseudotexanum de Grossouvre; Andert, p. 404, text-fig. 3.

1945 Texanites pseudotexanus (Grossouvre); Rosenkrantz, p. 442, fig. 2.

Lectotype: here designated GPIB 87, is the original of Schlüter, 1876, pl. 41, figs 1, 2, from the "Emscher-Mergel der Zeche Ewald bei Herten in Westfalen", reillustrated here as Fig. 6.

Material: MMH 5164, the original of Rosenkrantz, 1945, fig. 2, from the Bavnodde Greensand of Bavnodde; GM 1984.645, from the same unit at Forchhammers Odde.

Description: MMH 5164 is a short section of whorl with a maximum preserved whorl height of $47 \mathrm{~mm}$, and somewhat distorted. The whorl section appears to have been compressed polygonal with the greatest breadth at the lateral (2) tubercle. Parts of nine ribs are preserved on the specimen, which is $115 \mathrm{~mm}$ long. The ribs are very coarse, blunt, straight and prorsiradiate, and narrower than the interspaces. There are well-devel- oped umbilical bullae (1), coarse lateral (2) and submarginal (3) tubercles that seem to be clavate rather than bullate. The marginal (4) tubercles are of comparable size and distinctly clavate, while the external (5) row are much more elongate and lie at the termination of the ribs. A broad smooth zone separates these tubercles from a blunt, feebly undulose siphonal keel. GM 1984.645 has a similarly coarse ornament and shows only part of the inner flank with umbilical (1) and lateral (2) tubercles.

Discussion: The Bornholm material is indistinguishable from the crushed lectotype, shown here in Fig. 6. There are several other Texanites (Texanites) species based on European type material, but existing collections are too small to resolve relationships and it is perfectly possible that the forms discussed below represent no more than a single variable species. Thus $T$. (T.) quinquenodosus (Redtenbacher, 1873) (see recent revision by Kennedy, Summesberger \& Klinger 1981, p. 126, figs 8-16) has 27-32 ribs per whorl in Austrian material versus 24 in the lectotype of $T$. (T.) pseudotexanum and the ornament is altogether more delicate. $T$. (T.) gallicus Collignon, 1948 (see revision in Kennedy 1987, p. 770, pl. 80, figs $4-7$; pl. 81, figs $1-6$ ) has $28-29$ ribs per whorl in the lectotype (de Grossouvre 1894, pl. 17, fig. 1), and umbilical (1), lateral (2), submarginal (3) and marginal (4) tubercles that are rounded, rather than clavate. T. (T.) hispanicus Collignon, 1948 is said to have ribbing arising on the umbilical wall and a lateral (2) tubercle that migrates outwards to mid-flank during ontogeny.

Occurrence: Santonian of Westphalia in the German Federal Republic, Czechoslovakia, and Bornholm.

Genus and Subgenus Protexanites Matsumoto, 1955

Type species: Ammonites bourgeoisianus d'Orbigny, 1850 p. 212 , by original designation.

Protexanites (Protexanites) sp.

Pl. 7, fig. 3

Material: MGUH 19696 from the Bavnodde Greensand of Risenholm at Blykobbe $\AA$. 


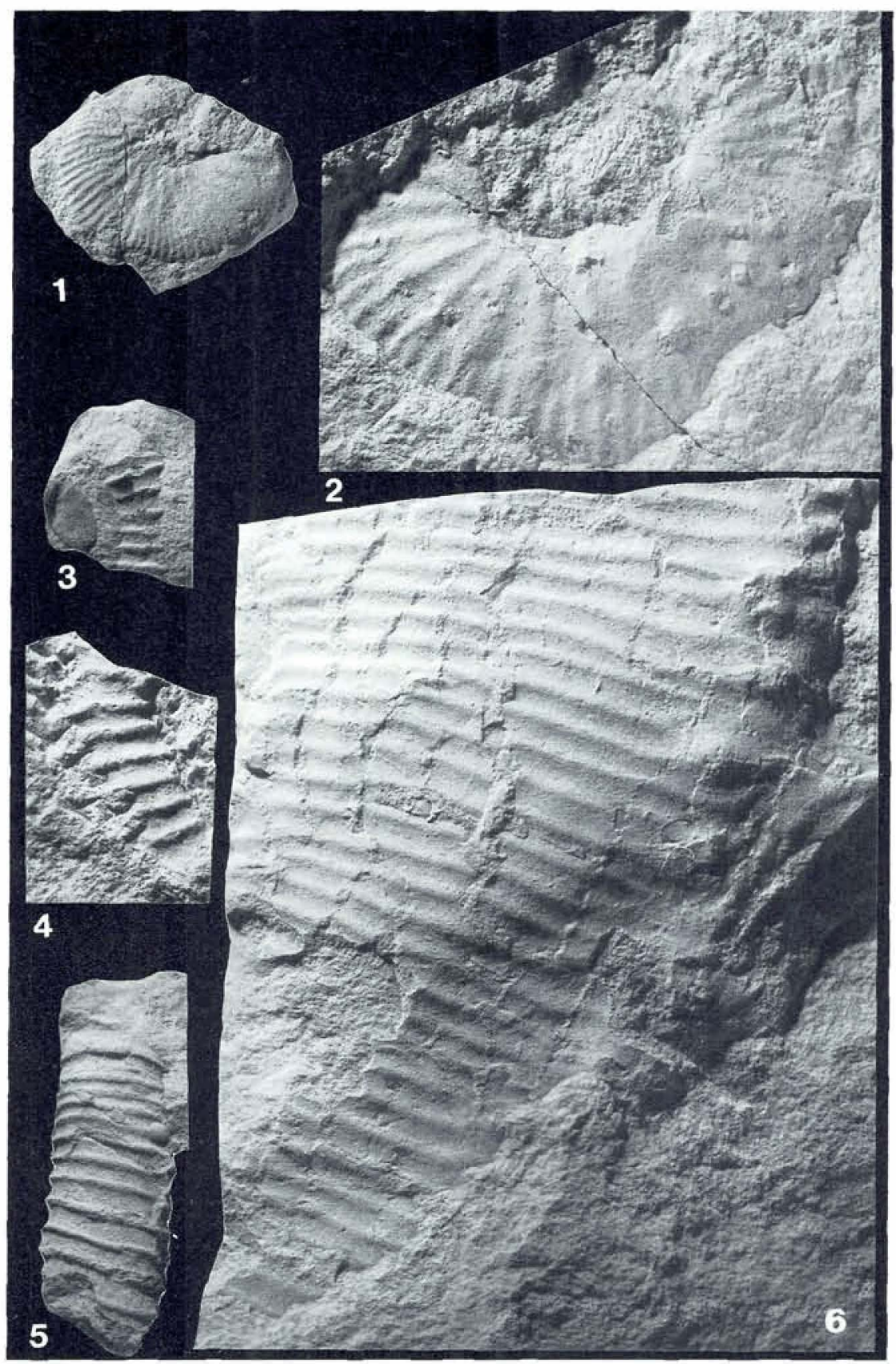

Plate 3:

Fig. 1. Yezoites sp. MGUH 19716.

Fig. 2. Scaphites (Scaphites) kieslingwaldensis kieslingwaldensis Langenhan \& Grundey. 1891. MGUH 19706.

Figs 3, 4, 5. Scalarites sp? 3 is MGUH 19698: 4 is MGUH 19699; 5 is MGUH 19700.

Fig. 6. Neocrioceras (Schlueterella) cf. maderi Immel. Klinger \& Wiedmann, 1982. MGUH 19701.

All figures are natural size. 
Description and Discussion: The fragment has a maximum preserved whorl height of $17.5 \mathrm{~mm}$, and is $28 \mathrm{~mm}$ long. Parts of five straight prorsiradiate, ribs are preserved, with umbilical bullae (1), conical lateral (2) and clavate marginal (4) tubercles. The specimen is specifically indeterminate.

Suborder Ancyloceratina Wiedmann, 1966

Superfamily Turrilitaceae Gill, 1871

Family Nostoceratidae Hyatt, 1894

Genus Nostoceras Hyatt, 1894

Type species: Nostoceras stantoni Hyatt, 1894, p. 569 , by original designation.

Subgenus Eubostrychoceras Matsumoto, 1967

Type species: Eubostrychoceras indopacificum Matsumoto, 1967 , p. 333, pl. 18 , fig. 1 ; by original designation.

Nostoceras (Eubostrychoceras) cf. saxonicum (Schlüter, 1876)

PI. 1, fig. 1.

\section{Compare:}

1841 Turrilites polyplocus Roemer, p. 92 (pars), pl. 14, fig. 2 only, non $1(=N$. (Bostrychoceras) polyplocum.

1872 Turrilites geinitzi Schlüter, p. 113.

1876 Turrilites saxonicus Schlüter, p. 135, pl. 35, fig. 10.

Material: MGUH 19697, from the Bavnodde Greensand of Jydegård.

Description and Discussion: The specimen is a fragment of half a whorl of a helicoid form, and the whorl section has been crushed into an ellipse. Ornament consists of extremely fine, dense, even ribs that are markedly convex on both upper and lower whorl faces of the specimen. This dense even ornament matches that of Turrilites saxonicus of Schlüter as shown by the lectotype, the original of Roemer 1841, pl. 14, fig. 2 only, designated by Wiedmann (1962, p. 202). Wiedmann regarded saxonicum of Schlüter as a subspecies of 'Helicoceras' indicum of Stoliczka (1866 p. 184, pl. 86, figs 1, 2), with Heteroceras elongatum of Whiteaves (1903 p. 331, pl.
44, fig. 2) as a further subspecies. Matsumoto (1967 p. 332) adopted a rather different view regarding saxonicum and indicum as distinct species of Eubostrychoceras, a view followed here. $N$. (E.) saxonicum was originally described from the Turonian of Germany, and subsequently noted from the Turonian or Coniacian of Madagascar, India and (?) Japan (Matsumoto 1967, p. $332,334)$. The Bornholm fragment is from the Lower Santonian.

Family Diplomoceratidae Spath, 1926

Subfamily Diplomoceratinae Spath, 1926

Genus Scalarites Wright \& Matsumoto, 1954

Type species: Helicoceras scalare Yabe, 1904, p. 9 , pl. 3, fig. 2; by original designation.

Scalarites sp?

Pl. 3, figs 3, 4, 5

Material: MGUH 19698-19700, from the Arnager Limestone of Arnager.

Description and Discussion: All specimens are fragments only; the best is MGUH 19700 , some $38.5 \mathrm{~mm}$ long. It is crushed flat like the other specimens, and is ornamented by strong, sharp annular ribs separated by somewhat wider interspaces. At one end, three ribs are crowded together just before a wider, accentuated interspace and a flared rib. The fragments closely resemble Crioceras serta Müller \& Wolleman, 1906 (p. 20, pl. 9, fig. 3; pl. 10, figs 1-3), a Scalarites from the Santonian-Campanian of Braunschweig, as well as poor fragments from the Coniacian of Dieulefit in Drôme, France (Kennedy 1984, p. 140, pl. 32, figs 7-10).

Genus Neocrioceras Spath, 1921

Type species: Crioceras spinigerum Jimbo, 1894, p. 184 , pl. 24 , fig. 1 ; by original designation.

\section{Subgenus Schlueterella Wiedmann, 1962}

Type species: Ancyloceras pseudoarmatum Schlüter, 1872, p. 99, pl. 31, figs 1-3.

Neocrioceras (Schlueterella) cf. maderi Immel, Klinger \& Wiedmann, 1982

Pl. 3, fig. 6; Pl. 6, fig. 1; Pl. 7, fig. 5 
1982 Neocrioceras (Neocrioceras) maderi Immel, Klinger \& Wiedmann, p. 24, pl. 9, fig. 2; pl. 11, figs $1,2$.

Holotype: Bayerische Staatsammlung fur Paläontologie und historische Geologie, Munich Collections, no. 1981.1.107, from the Lower Santonian of Brandenburg Tirol, Austria.

Material: MGUH 19701-19702, from the Arnager Limestone of Arnager; MGUH 19703 and GM 1987.638 from the same locality and localised as from $2-3 \mathrm{~m}$ above the base of the unit.

Description: MGUH 19703 and GM 1987.638 are slightly curved, suggesting coiling in a large open criocone. The rib index is $8-9$, the ribs crowded and evenly developed on the dorsolateral area, transverse or feebly concave on the flank. Small sharp tubercles are present high on the flank. They link two or three ribs, which pinch in to the meet the tubercle, while there are two or three ribs between the tuberculate groups that extend across the venter. Large ventral spines occur at the same spacing as the outer lateral tubercles, to which they are linked by pairs of ribs, while ribs that lack the outer lateral tubercle may also connect to these spines, giving a distinctive and irregular appearance to the outer flank ornament. This is shown particularly well by MGUH 19702 (Pl. 6, fig. 1). The largest specimen, MGUH 19701, lacks the dorsal part of the flank, but still has a whorl height of $67 \mathrm{~mm}$ (Pl. 3, fig. 6). The ribs are even, feebly flexuous, and separated by slightly wider interspaces. The lateral tubercles have migrated to a position high on the flank, and link groups of ribs, with one or two ribs between. The ventral spines are enormous and seem to have been fewer in number than the lateral tubercles.

Discussion: The Campanian Neocrioceras (Schlueterella) pseudoarmatum (Schlüter, 1872) (see Kennedy 1986, text-fig. 37) has coarser ribs and tubercles much lower down the flank, as does $N$. (S.) crassetuberculatum (Collignon, 1966, pl. 456, figs 1857-1859) of the Santonian. $N$. (S.) compressus Klinger, 1976 (p. 74, pl. 33, fig. 5; text-figs $8 ; 10 \mathrm{~g}$ ), also of the Santonian, has tuberculate ribs stronger than nontuberculate ones, and lateral tubercles below mid-flank. $N$. (S.) kawadai Matsumoto \& Miyauchi, 1984 (p. 61, pl. 26, fig. 1; pl. 27, figs 3-4; pl. 28, fig. 2; pl. 29, fig. 1; pl. 30, figs 1-2; pl. 31, fig. 3; text-fig. 9) of the Campanian, has lateral tubercles well down the flank. Rib density and tuberculation of the $\mathrm{Ne}$ ocrioceras n.sp. of Scott \& Cobban, 1964 (p. 11, pl. 3, figs 1,2 ) matches that of the present material, and suggests the possible presence of $N$. (S.) cf. maderni in the Coniacian of the US Westem Interior.

Occurrence: Coniacian of Bornholm.

Family Baculitidae Gill, 1871

Genus Baculites Lamarck, 1799

Type species: Baculites vertebralis Lamarck, 1801 , p. 80 , by subsequent designation by Meek, 1876, p. 391.

Baculites cf. fuchsi Redtenbacher, 1873

Pl. 7, figs $1 \mathrm{a}, 1 \mathrm{~b}$.

Compare:

1873 Baculites fuchsi Redtenbacher, p. 134, pl. 30, fig. 15.

1982 Baculites fuchsi Redtenbacher, 1873; Immel, Klinger \& Wiedmann, p. 28, pl. 11, fig. 8 (with synonymy).

Material: MGUH 19704, from the Bavnodde Greensand, Risenholm.

Description and Discussion: The fragment shows flank and venter of a Baculites with a maximum preserved whorl height of $20.5 \mathrm{~mm}$. The flanks are smooth, but the venter bears coarse prorsiradiate ribs, at their maximum strength over the siphonal area. Among described species the fragment resembles the large specimen of Baculites fuchsi figured by Summesberger (1979, pl. 1, figs 2-4) although the ventral ribbing is if anything even coarser.

Occurrence: $B$. fuchsi is known from the Santonian Gosau Group of the Brandenberg Tirol and the Gosau Basin, of Austria, occurring in both Upper and Lower Santonian.

Baculites cf. incurvatus Dujardin, 1837

Pl. 1, figs 2a, 2b 


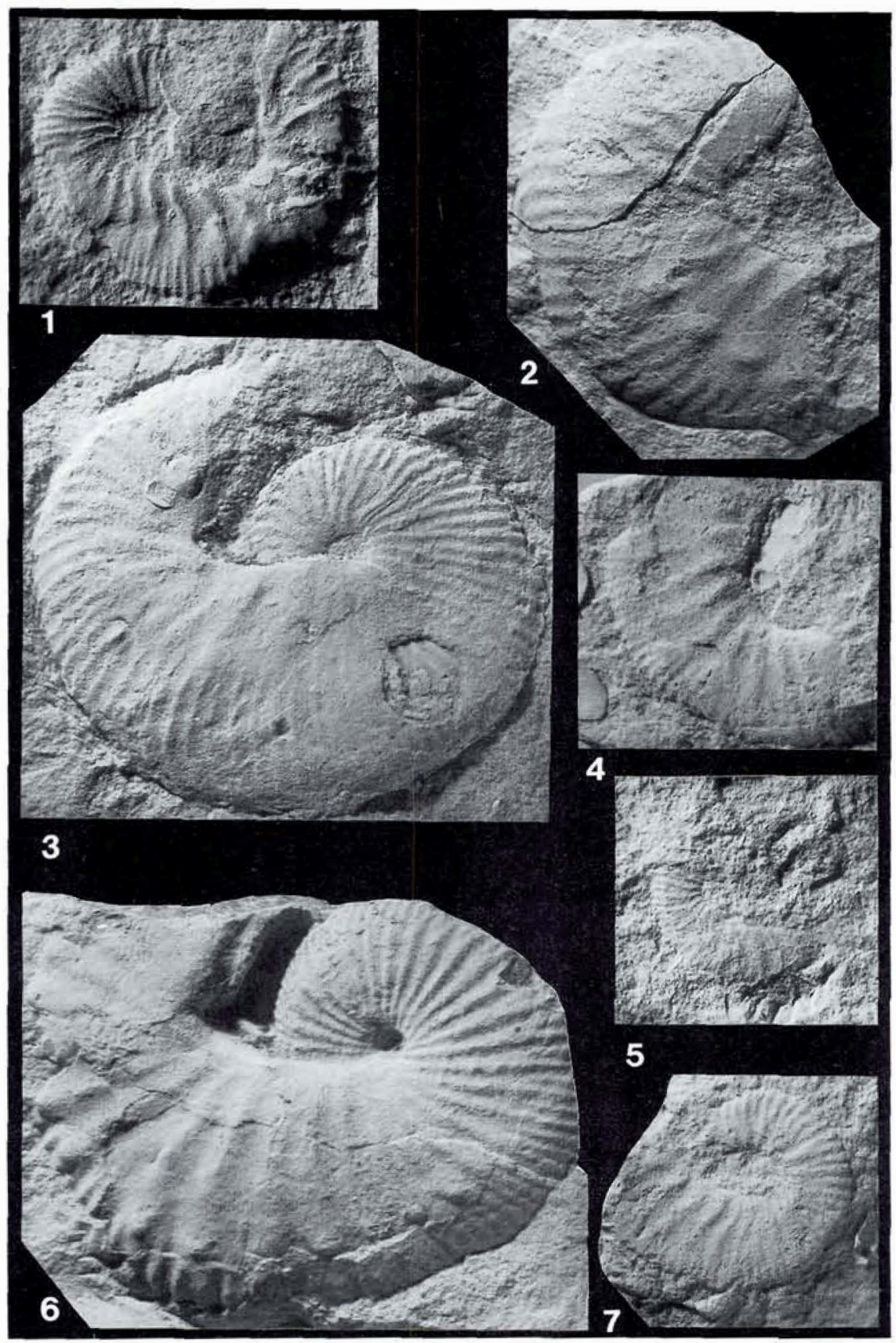

Plate 4:

Figs 1, 3, 24, 5, 7. Yezoites sp. 1 is MGUH 19725; 3 is MGUH 19717; 4 is MGUH 19718; 5 is MGUH 19719: 7 is MGUH 19720. Figs 2. 6. Scaphites (Scaphites) kieslingswaldensis kieslingswaldensis Langenhan \& Grundey, 1891. 2 is MGUH 19707;6 is MGUH 19708.

All figures are natural size. 

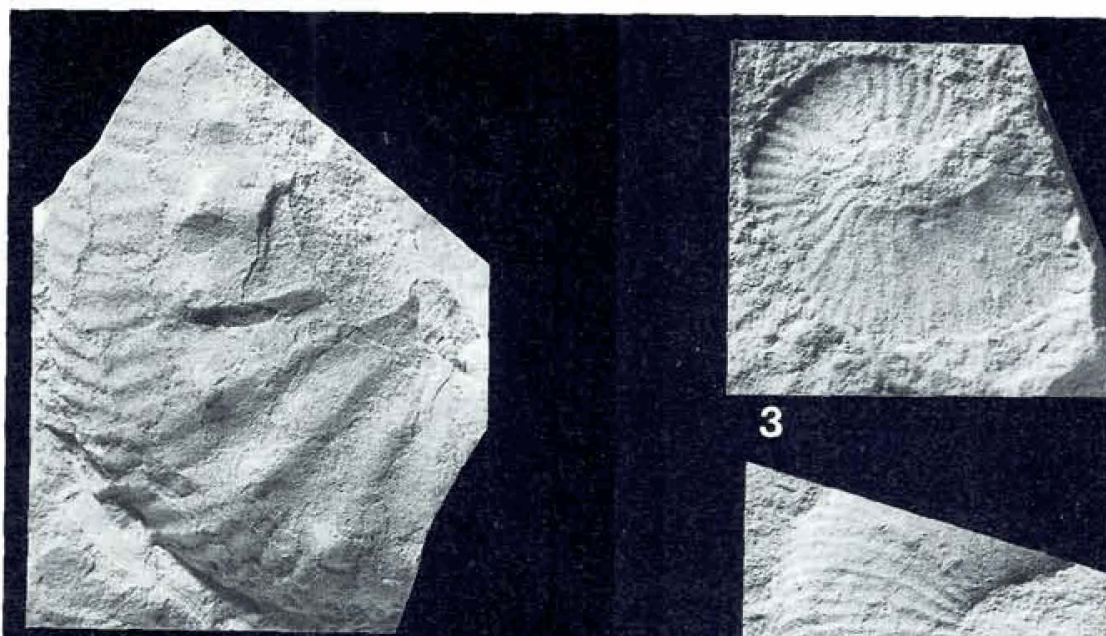

3
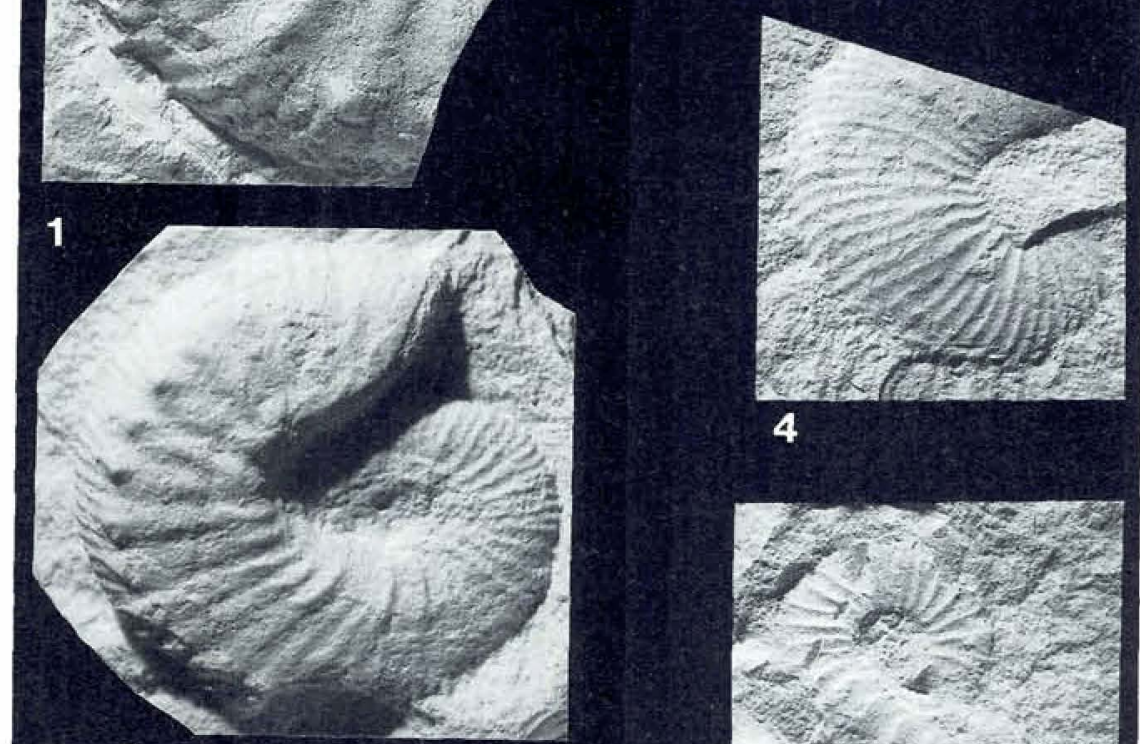

2
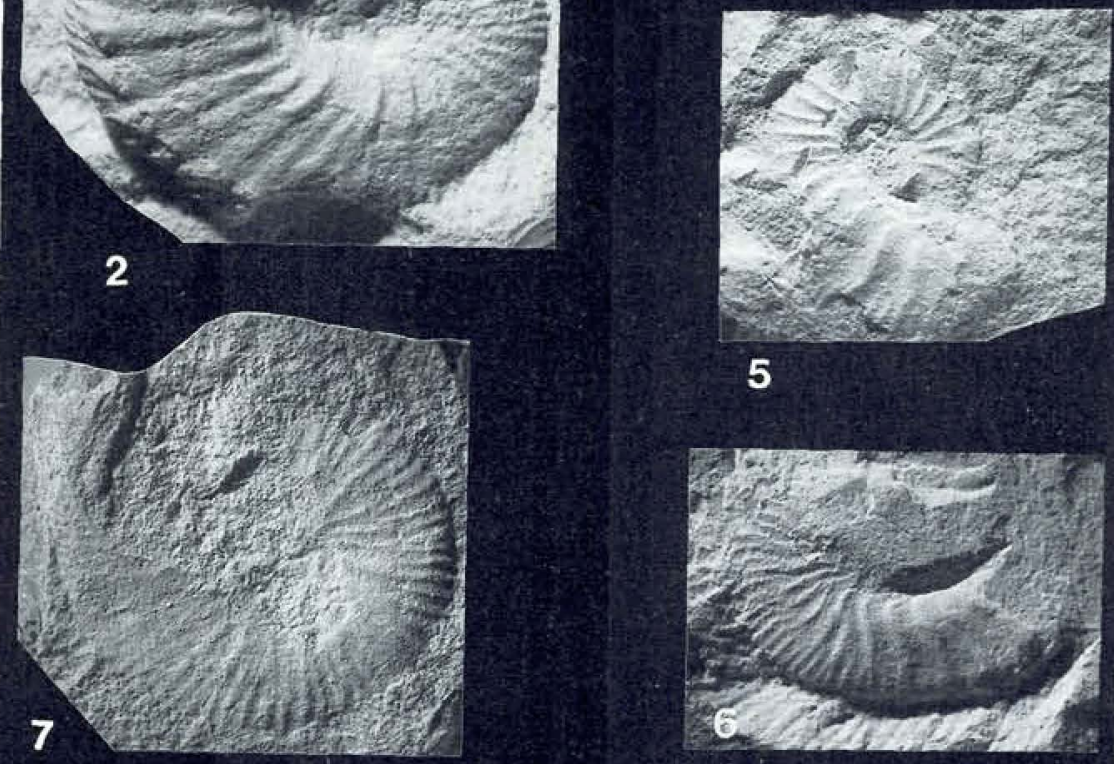

5

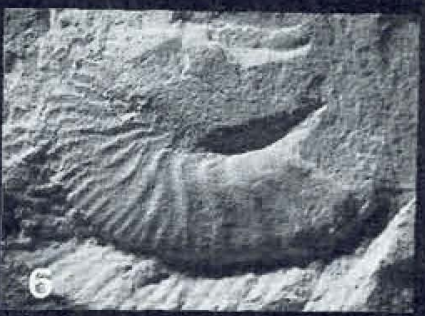

Plate 5:

Fig. 1. Scaphites (Scaphites) kieslingswaldensis kieslingswaldensis Langenhan \& Grundey, 1891. MGUH 19708.

Fig. 2. Scaphites (Scaphites) kieslingswaldensis fischeri Riedel, 1931. MMH 1810.

Figs 3, 4, 5, 6, 7. Yezoires sp. 3 is MGUH $19720 ; 4$ is MGUH 19721; 5 is MGUH 19722; 6 is MGUH $19723: 7$ is MGUH 19724 All figures are natural size. 


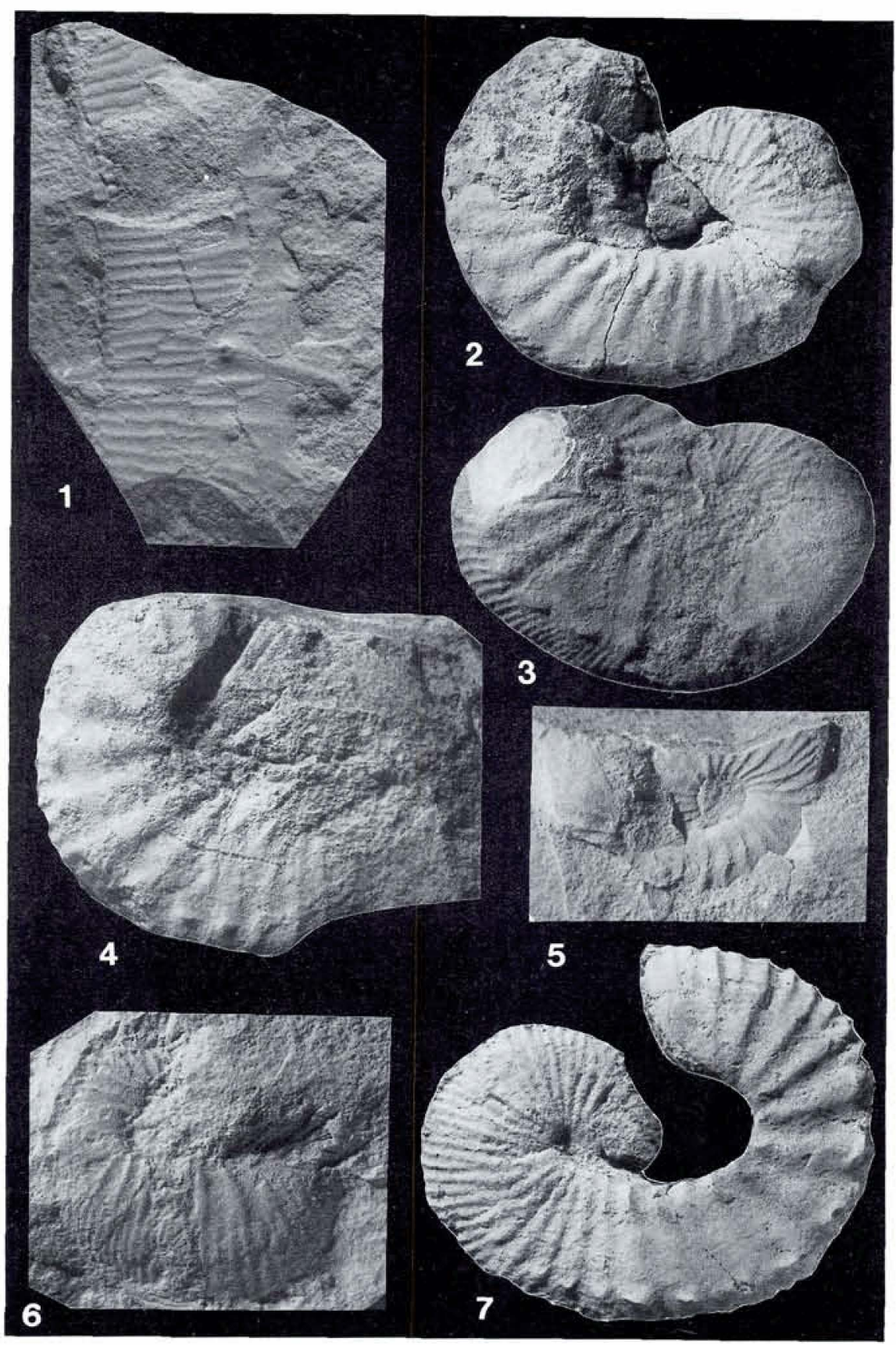

Plate 6:

Fig. 1. Neocrioceras (Schlueterella) cf. maderi Immel, Klinger \& Wiedmann, 1982. MGUH 19702.

Figs 2, 3, 4. 7. Scaphites (Scaphites) kieslingswaldensis fischeri Riedel, 1931. 2 is MGUH 19710; 3 is MGUH 19712:4 is MGUH 19713.

7 is MMH 1811.

Fig. 5. Yezoites sp. MGUH 19726

Fig. 6. Indeterminate scaphitid. MGUH 19727.

All figures are natural size. 


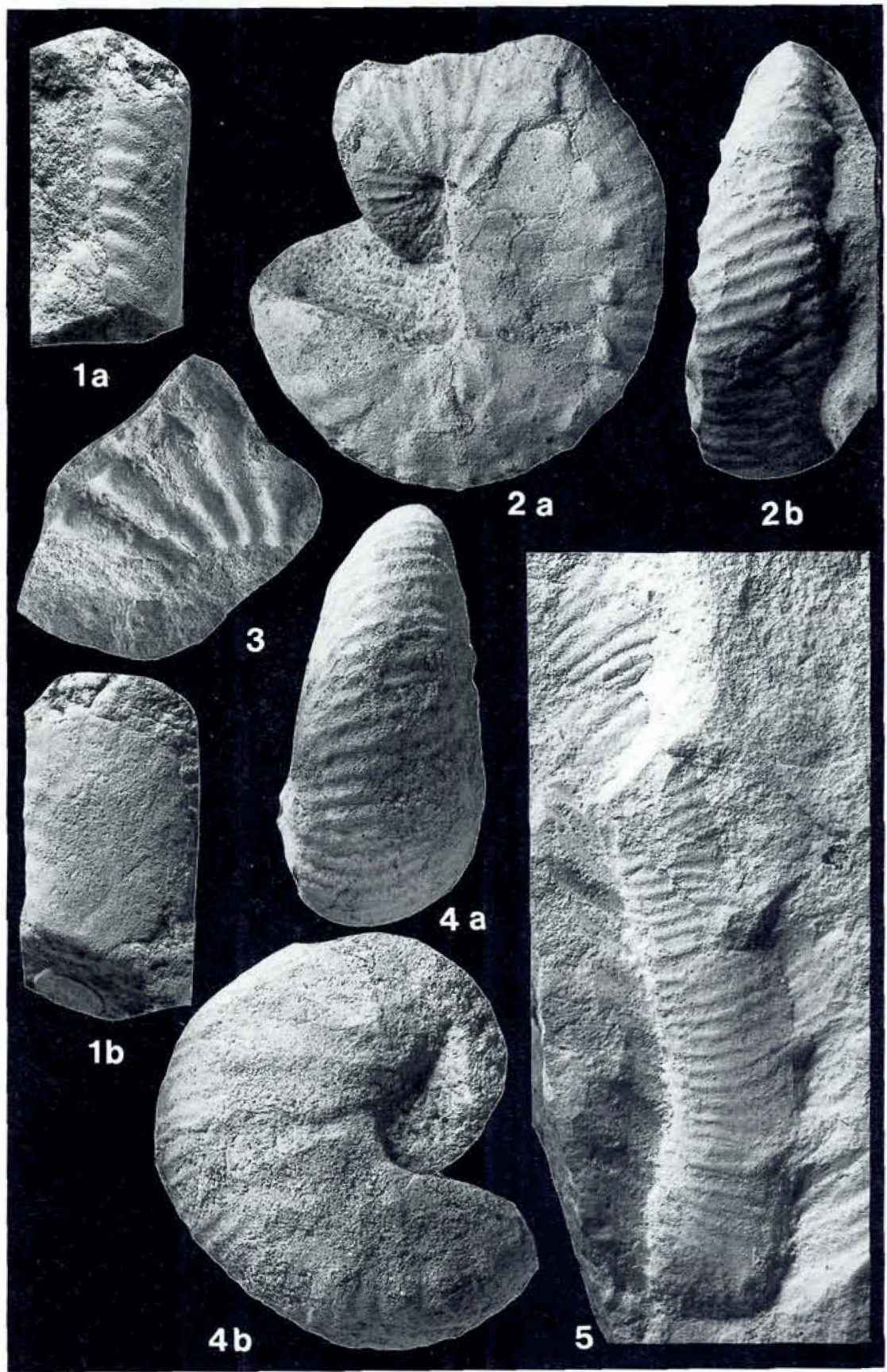

Plate 7:

Fig. 1. Baculites cf. fuchsi Redtenbacher, 1873. MGUH 19704.

Figs 2, 4. Scaphites (Scaphites) kieslingswaldensis fischeri Riedel, 1931. 2 is MGUH 19714: 4 is MGUH 19715.

Fig. 3. Protexanites (Proteranites) sp. MGUH 19696.

Fig. 5. Neocrioceras (Schlueterella) maderi Immel, Klinger \& Wiedmann, 1982, MGUH 19703. All figures are natural size. 
1837 Baculites incurvatus Dujardin, p. 232, pl. 17, fig. 13.

1984 Baculites incurvatus Dujardin, 1837; Kennedy, p. 143, pl. 32, figs $12,15-19 ;$ pl. 33, figs 1-22; text-figs 41,42 F-M.

Type: Lectotype, designated by Immel, Klinger \& Wiedmann (1982 p. 27), is MNHP R 1025a.

Material: MGUH 19705, from the Bavnodde Greensand west of Bavnodde.

Description and Discussion: Specimen is a crushed fragment $47 \mathrm{~mm}$ long, with a maximum preserved whorl height of $17.1 \mathrm{~mm}$. Although ill-preserved, it shows two conical dorsolateral bullae, suggesting reference to $B$. incurvatus, discussed by Immel, Klinger \& Wiedmann (1982) and Kennedy (1984).

Occurrence: $B$. incurvatus first appears in the Middle Coniacian in Touraine and Aquitaine in France and occurs in the Upper Coniacian in Touraine and the Santonian in Touraine, Aquitaine, the Germanies, Czechoslovakia and Austria.

Superfamily Scaphitaceae Gill, 1871

Family Scaphitidae Gill, 1871

Subfamily Scaphitinae Gill, 1871

Genus and Subgenus Scaphites Parkinson, 1811

Type species: Scaphites equalis J. Sowerby, 1813, p. 53, pl. 18 , figs $1-3$; by subsequent designation by Meek (1876, p. 413).

Scaphites (Scaphites) kieslingswaldensis kieslingswaldensis Langenhan \& Grundey, 1891

Pl. 3, fig. 2; Pl. 4, figs 2, 6; Pl. 5, fig. 1

1891 Scaphites kieslingswaldensis Langenhan \& Grundey, p. 9, pl. 1, fig. 1.

1987 Scaphites kieslingswaldensis kieslingswaldensis Langenhan \& Grundey, 1891; Kaplan, Kennedy \& Wright, p. 14, pl. 4, figs 3-6; pl. 5, figs 1-5 (with full synonymy).

Type: The holotype by monotypy is the original of Langenhan \& Grundey, 1891, pl. 1, fig. 1, from the Coniacian of Kieslingswalda, southeast of Klodzki (Glatz), Poland.
Material: MGUH 97060-19709, GM 1918.188, 1987.641, and 1989.25. All are from the Arnager Limestone, with precisely located specimens $2 \mathrm{~m}$ from the base (GM 1989.25) and from the very top between Arnager and Horsemyre Odde (MGUH 19708).

Description: Macroconchs (Pl. 3, fig. 2; Pl. 4, figs 2, 6; PI. 5, fig. 1) are up to $74 \mathrm{~mm}$ long. The spire is ornamented by straight primary ribs that branch high on the flank into two or three secondary ribs, while there are occasional intercalatories; small tubercles are present at the point of branching on the outer whorl. There are 6-7 distant ribs on the shaft with umbilical bullae of variable strength as well as ventrolateral clavi, where the ribs break into two or three coarse secondaries which, with occasional intercalatories, strengthen and loop over the venter. Ribs and tubercles extend around the final hook and weaken somewhat just before the aperture.

Microconchs (Pl. 4, fig. 1) vary from $36-56 \mathrm{~mm}$ long and have an open umbilicus to the spire and narrower body chamber with concave dorsal edge.

Discussion: S. kieslingswaldensis kieslingswaldensis is fully discussed by Kaplan et al. (1987, p. 14). It differs from the older $S$. kieslingswaldensis doylei Wright, 1979, which has only incipient umbilical tubercles on the shaft, no distinct tubercles on the spire in macroconchs and incipient ones only in microconchs.

Occurrence: The nonate subspecies first appears in the middle part of the Lower Coniacian and ranges into the Upper Coniacian. It is known from Spain, Poland, Czechoslovakia, the Germanies, Austria and Madagascar.

Scaphites (Scaphites) kieslingswaldensis fischeri Riedel, 1931

Pl. 2, figs 1, 2a, 2b; Pl. 5, fig. 2; Pl. 6, figs 2, 3, 4, 7; Pl. 7, figs 2a, 2b; 4a, 4b.

1874 Scaphites inflatus Roemer; Schlüter, p. 24. 1874 Scaphites binodosus Roemer; Schlüter, p. 24.

1902 Scaphites inflatus F. A. Roemer; Ravn, p. 252.

1902 Scaphites binodosus F. A. Roemer; Ravn, p. 253. 
1906 Scaphites binodosus A. Roemer; Müller \& Wollemann, p. 16, pl. 9, figs 4-6; pl. 10, fig. 4 .

1921 Scaphites inflatus Römer; Ravn, p. 35, pl. 3 , fig. 5 .

1921 Scaphites binodosus? Römer; Ravn, p. 36, pl. 3, fig. 6.

1931 Scaphites bärtlingi Riedel, p. 701, pl. 79, figs 3,4 .

1931 Scaphites fischeri Riedel, p. 704, pl. 79, figs 5,6 .

1971 Scaphites bärtlingi Riedel; Ulbrich, pl. 5, fig. 5 .

1986b Scaphites fischeri Riedel; Kennedy, p. 124, text-fig. 40.

1987 Scaphites kieslingswaldensis fischeri Riedel; Kaplan, Kennedy \& Wright, p. 16.

Lectotype: Here designated, the original of Riedel, 1931, pl. 79, fig. 6 .

Material: MGUH 19710-19715, GM 1923.403, 1923.406. 1976.670, 1904.647, 1929.48, 1984.646, $1984.649,1989.27,1989.28$, MMH 1810 (the original of Ravn, 1921, pl. 3, fig. 5) MMH 1811 (the original of Ravn, 1921, pl. 3, fig. 6), all from the Bavnodde Greensand of Bavnodde, Forchhammers Odde, Horsemyre Odde, Blykobbe $\AA$.

Description: The species is markedly dimorphic. In microconchs (e.g. Pl. 6, fig. 7) the umbilicus is open, the body chamber slender, with a concave curve to the umbilical wall. In macroconchs the umbilicus is partially occluded by a bulge on the umbilical wall of the initial part of the shaft and the body chamber is much stouter (PI. 7, figs 2, 4). Ribbing on the spire is quite coarse. Straight primaries bifurcate on the outer flank, the point of bifurcation commonly marked by a conical tubercle. The secondary ribs and some intercalatories of similar length pass straight across the venter. There are about twelve primary ribs on the shaft and hook. They arise from strong, crowded umbilical bullae and are coarse, straight and prorsiradiate across the flank, terminating at strong ventrolateral clavi. Two, rarely three coarse secondary ribs loop between clavi, and there are occasional intercalated ribs. Ribbing and tuberculation decline markedly just before the adult aperture.
Discussion: Scaphites kieslingswaldensis fischeri is regarded as the lineal descendant of $S . k$. kieslingswaldensis, following Kaplan et al. (1987), and is afforded subsecific status; it differs from the nominate subspecies in the more numerous primary ribs on the spire with umbilical bullae and much more elongate ventral clavi. This subspecies probably gave rise to Scaphites binodosus (Roemer, 1841) of the Campanian (see Kennedy, 1986b, text-fig. 39) by progressive size increase and the development of more numerous tubercles on the shaft and spire, the umbilicals becoming spirally elongate.

Kennedy (1986b, p. 122) recognised Scaphites baertlingi Riedel, 1931 (pl. 79, figs 3, 4) and $S$. fischeri Riedel, 1931 (pl. 79, figs 5, 6) as dimorphs and selected fischeri as the name of the species, as first revising author.

Occurrence: Kennedy (1986b) erroneously referred this species to the Lower Campanian only; the careful records of Müller \& Wolleman (1906), Riedel (1931), Arnold (1964) and Ulbrich (1971) show it rather occurring from the Lower Santonian to Lower Campanian in the Germanies. It is Lower Santonian on Bornholm.

Subfamily Otoscaphitinae Wright, 1953

Genus Yezoites Yabe, 1910

Type species: Scaphites perrini Anderson, 1902, p. 114, pl. 2, figs 71-73; by subsequent designation by Diener (1925, p. 213).

Yezoites sp.

PI. 3, fig. 1; PI. 4, figs 1, 3, ?4, 5, 7; PI. 5, figs 3-7; Pl. 6, fig. 5.

Material: MGUH 19716-19725, GM 1976.3330, 1934.291, 1938.57, 1989.26, all from the Arnager Limestone of Arnager.

Description and Discussion: What seems to be a second species of scaphitid is represented by a number of crushed fragments from the Arnager Limestone, as well as a few crushed but complete individuals.

Microconchs are an estimated $33 \mathrm{~mm}$ in maximum length. Ribs on the spire bifurcate on the outer flank and there are some intercalatories. On the narrow shaft, which does not occlude the 
umbilicus, there are up to 7 narrow flexuous ribs which bi- or trifurcate on the outer flank, where intercalated ribs also arise, all these ribs crossing the outer flank in a marked convexity.

What may be the macroconch, MGUH 19717 (PI. 4, fig. 3), is $62 \mathrm{~mm}$ long. The spire is ornamented by straight to feebly flexuous primary ribs that bifurcate around mid-flank or not and are accompanied by long intercalated ribs; there are no tubercles. An umbilical bulge occludes part of the umbilicus on the spire. On the shaft, narrow, distant, primary ribs are prorsiradiate to mid-flank where they bifurcate; intercalated ribs arise at about the same point, and all these ribs strengthen over the venter, flexing back and becoming markedly convex.

Absence of tubercles distinguishes this material from Scaphites (Scaphites) kieslingswaldensis and its subspecies. The shaft ornament of microconchs recalls that of Yezoites bladenensis (Schlüter, 1871) and Y. puerculus (Jimbo, 1894), and for this reason the material is placed in Yezoites although larger by far than any other material referred to the genus.

Acknowledgements. We thank the Staff of the Geological Museum, Copenhagen, the Department of Earth Sciences, Oxford, and the University Museum, Oxford, for technical support, and C. W. Wright (Seaborough) for valuable discussion. Dr. N. Solakius (Lund) provided valuable data on foraminifera, for which we are especially grateful.

Ammonites were collected in recent years by W.K.C, aided by M.-G. Schulz (Kiel), F. Schmid (Künzelsau) and S. L. Jakobsen (Copenhagen). Kennedy acknowledges the financial support of the Natural Environment Research Council (U.K.).

\section{Dansk sammendrag}

Ammonitterne fra Arnager Kalk Formationen og Bavnodde Grønsand Formationen på Bornholm beskrives: fem arter optræder Arnager Kalken på typelokaliteten vest for Arnager, og syv arter optræder i Bavnodde Grønsandet på sydkysten og på Nyker blokken. Alderen af de to formationer diskuteres på basis af ammonitter, inoceramide muslinger, belemniter og foraminiferer. Fra Arnager Kalken beskrives bl.a. Peroniceras tridorsatum, som er ledefossil for Mellem Coniacien og Scaphites (S.) kieslingswaldensis kieslingswaldensis, som først optræder i det mellemste Nedre Coniacien og fortsætter op i Øvre Coniacien. Fra Bavnodde Grønsandet beskrives bl.a. Scaphites (S.) kieslingswaldensis fischeri, som andre steder i Europa først optræder i Nedre Santonien.

Arnager Kalken på typelokaliteten er af Mellem Coniacien alder på basis af ammonitter, Nedre Coniacien alder på basis af inoceramide muslinger og af Coniacien alder på basis af foraminiferer. Bavnodde Grønsandet kan henføres til Øvre Conia-
cien-Nedre Santonien på basis af ammonitter, belemniter og inoceramide muslinger.

\section{References}

Anderson, F. M. 1902: Cretaceous Deposits of the Pacific Coast. Proc. Calif. Acad. Sci., (3) Geol. 2; 154 pp., 12 pls.

Andert, H. 1934: Die Kreideablagerungen zwischen Elbe und Jenschken. Teil III. Die Fauna der obersten Kreide in Sachsen, Böhmen und Schlesien. Abh. preuss geol. Landesanst. (NF) 159, 477 pp., 19 pls.

Arnold, H. 1964: Die Fossilführung des Bottroper Mergels in der Ziegelei Ridderbusch westlich Dorsten. Förtschr. Geol. Rheinld. Westf. 7 199-212, 5 pls.

Birkelund, T. 1957: Upper Cretaceous belemnites from Denmark. Biol. Skr. Dan. Vid. Selsk. 9, 69 pp.

Christensen, W. K. 1971: Belemnitella propinqua propinqua (Moberg, 1885) from Scandinavia. Bull. Geol. Soc. Denmark 20, 369-384.

Christensen, W. K. 1973: The belemnites and their stratigraphical significance. In Bergström, J., Christensen, W. K., Johansson, C. and Norling, E.: An extension of Upper Cretaceous rocks to the Swedish west coast at Särdal. Bull. Geol. Soc. Denmark 22, 113-140.

Christensen, W. K. 1985: The Albian to Maastrichtian of southern Sweden and Bornholm, Denmark: a review. Cretaceous Research 5, 313-327. (misdated 1984).

Collignon, M. 1948: Annmonites néocrétacées du Menabe (Madagascar). I. Les Texanitidae. Annls Géol. Serv. Min. Madagascar, 13, 49-107 (1-63), pls. 7-20 (1-14); 14, 7-101 (64-120), pls. 15-23.

Collignon, M. 1966: Atlas des fossiles characteristiques de Madagascar (Ammonites). 14, Santonien. x 134 pp., pls. 455-513. Service géologique, Tananarive.

Diener, C. 1925: Ammonoidea neocretacea. Fossilium Cat. (1: Animalia), 29, 244 pp.

Dujardin F. 1837: Mémoire sur les couches du sol en Touraine et déscription des coquilles de la craie et des Faluns. Mém. Soc. geol. Fr. 2, 211-311, pls. 15-20.

Ernst, G. 1968: Die Oberkreide-Aufschlüsse im Raume Braunschweig-Hannover und ihre stratigraphische Gliederung mit Echinodermen und Belemniten. Beih. Ber. $\mathrm{Na}$ turh. Ges. 5, 235-284.

Fallot, E. 1885: Etude géologique sur les étages moyens et supérieurs du terrain Crétacé dans le sud-Est de la France. Ann. Sci. géol. Paris 18, 1-268, 8 pls.

Gill, T. 1871: Arrangement of the Families of Mollusks. Smithson. Misc. Collns 227 , xvi +49 pp.

Gravesen, P., Rolle, F. \& Surlyk, F. 1982: Lithostratigraphy and sedimentary evolution of the Triassic, Jurassic and Lower Cretaceous of Bornholm, Denmark. Danmarks Geol. Unders. B7, $51 \mathrm{pp}$.

Grossouvre, A. de 1894: Recherches sur la craie supérieure, 2, Paléontologie. Les ammonites de la craie supérieure. Mém. Serv. Carte Géol. dét. France, 264 pp., 39 pls. (misdated 1893).

Gry, H. 1956: Wealden aflejringeme på Bornholm, deres stratigrafi og tektonik. Bull. Geol. Soc. Denmark 13, 134-141. [In Danish].

Gry, H. 1960: Geology of Bornholm. Guide to excursions Nos A45 and C40. Intern. Geol. Congess. 21 Session, Norden, $16 \mathrm{pp}$.

Hyatt, A. 1889: Genesis of the Arietidae. Smithson. Contr. Knowl., 673, xi +238 pp., 14 pls.

Hyatt, A. 1894: Phylogeny of an Acquired Characteristic. Proc. Am. Phil. Soc. 32, 349-647, pls. 1-14. 
Hyatt, A. 1900: Cephalopoda, pp. 502-604 in Zittel, K. A. von 1896-1900, Textbook of Palaeontology, transl. Eastman, C. R. Macmillan, London and New York.

Immel, H., Klinger, H. C. \& Wiedmann, J. 1982: Die Cephalopoden des Unteren Santon der Gosau von Brandenberg/ Tirol, Osterreich. Zitteliana 8, 3-32, 11 pls.

Jeletzky, J. A. 1958: Die jüngere Oberkreide (Oberconiac bis Maastricht) Südwestrusslands und ihr Vergleich mit der Nordwest- und Westeuropas. Beih. Geol. Jb. 33, $157 \mathrm{pp}$.

Jensen, J. B. \& Hamann, E. 1989: Geological mapping of Mesozoic deposits along the eastem margin of the Rønne Graben, offshore Bornholm, Denmark. Bull. Geol. Soc. Denmark 37, 237-260.

Jimbo, K. 1894: Beiträge zur Kenntniss der fauna der Kreideformation von Hokkaido. Paläont. Abh. (N.S.) 2, 147194 , pls. $17-25$.

Kaplan, U., Kennedy, W. J. \& Wright, C. W. 1987: Turonian and Coniacian Scaphitidae from England and North-West Germany. Geol. Jb. A103, 5-39, 6 pls.

Kennedy, W. J. 1984: Systematic palaeontology and stratigraphic distribution of the ammonite faunas of the French Coniacian. Spec. Pap. Palaeont. 31, 160 pp., 33 pls.

Kennedy, W. J. 1985: Ammonite faunas of the Coniacian, Santonian and Campanian stages in the Aquitaine Basin. Géol. Méditerran., 10, 103-113.

Kennedy, W. J. 1986a: Ammonite biostratigraphy of the Albian to basal Santonian. Physics and Chemistry of the Earth 16, 129-182, 21 pls.

Kennedy, W. J. 1986b: Campanian and Maastrichtian ammonites from northern Aquitaine, France. Spec. Pap. Palaeont. 36,145 p., 23 pls.

Kennedy, W. J. 1987: Ammonites from the type Santonian and adjacent parts of northern Aquitaine, western France. $\mathrm{Pa}$ laeontology, 30, 765-782, pls. 80-82.

Kennedy, W. J., Hancock, J. M. \& Christensen, W. K. 1981: Albian and Cenomanian ammonites from the island of Bornholm (Denmark). Bull. Geol. Soc. Denmark 29, 203244.

Kennedy, W. J. Summesberger, H. \& Klinger, H. C. 1981: On Ammonites serratomarginatus Redtenbacher, 1873 and Ammonites quinquenodatus Redtenbacher, 1873. Pp. 117137 in Kennedy, W. J., Klinger, H. C. and Summesberger, H. 1973. Cretaceous faunas from Zululand and Natal, South Africa. Additional observations on the ammonite subfamily Texanitinae Collignon, 1948. Ann. S. Afr. Mus. $86,115-155$.

Klinger, H. C. 1976: Cretaceous heteromorph ammonites from Zululand. Mem. geol. Surv. Rep. S. Afr. 69, 142 pp., 43 pls.

Klinger, H. C. \& Kennedy, W. J. 1984: Cretaceous faunas from Zululand and Natal, South Africa. The ammonite subfamily Peroniceratinae Hyatt, 1900. Ann. S. Afr. Mus. 92, 113-294.

Kossmat, F. 1895-1898: Untersuchungen über die Sudindische Kreideformation. Beitr. Paläont. Öst.-Ung., 9, (1895): 97203 (1-107), pls. 15-25 (1-11); 11, (1897a): 1-46 (108153), pls. 1-8 (12-19); 11, (1898): 89-152 (154-217), pls. 14-19 (20-25).

Lamarck, J. P. B. A. de M. de 1799: Prodrome d'une nouvelle classiflcation des coquilles. Mém. Soc. Hist. Nat. Paris, (1799), 63-90.

Lamarck, J. P. B. A. de M. de 1801: Systême des Animaux sans vertebrès, vii $+432 \mathrm{pp}$. The author: Deterville, Paris.

Langenhan, A. \& Grundey, M. 1891: Das Kieslingswalder Gestein und sein Versteinerungen. Jahresb. Glatzer Gebirgs-Vereins $10,12 \mathrm{pp} ., 6 \mathrm{pls}$.

Matsumoto, T. 1955: Evolution of Peroniceratidae. Trans Proc. palaeont. Soc. Japan 18, 37-44.

Matsumoto, T. 1967: Evolution of Nostoceratidae. Mem. Fac. Sci. Kyushu Univ. Ser. D, Geol. 18: 331-347.
Matsumoto, T. 1979: Notes on Lewesiceras and Nowakites (Pachydiscid ammonites) from the Cretaceous of Hokkaido. Trans. Proc. Palaeont. Soc. Japan. N.S. 113, 30-44, pls. 4-7.

Matsumoto, T. \& Miyauchi, T. 1984: Some Campanian ammonites from the Soya area. Spec. Pap. Palaeontogr. Soc. Japan 27, 33-91, pls. 10-31.

Meek, F. B. 1876: A report on the invertebrate Cretaceous and Tertiary fossils of the upper Missouri country. In Hayden, F. V. Report of the United States Geological Survey of the Territories, 9, lxiv + 629 pp., 45 pls.

Müller, G. \& Wollemann, A. 1906: Die Mollusken fauna des Untersenon von Braunschweig und Ilsede. II. Die Cephalopoden. Abh. Preuss. geol. Landesanst. 47, 1-30, pls. 1-11.

Noe-Nygaard, N. \& Surlyk, F. 1985: Mound bedding in a sponge-rich Coniacian chalk, Bornholm, Denmark. Bull. Geol. Soc. Denmark 34, 237-249.

Orbigny, A. d' 1850: Prodrome de Paléontologie stratigraphigue universelle des animaux mollusques et rayonnés, 2, 428 pp. Paris: Masson.

Parkinson J. 1811: Organic Remains of a Former World, 3, xvi + 479 pp., 22 pls. Sherwood, Neily \& Jones. London.

Ravn, J. P. J. 1902: Molluskerne i Danmarks Kridtaflejringer. II. Scaphopoder, Gastropoder og Cephalopoder. Dan. Vid. Selsk. Skr., 6. Raekke, 11, 205-170. [In Danish].

Ravn, J. P. J. 1918: Kridtaflejringerne paa Bornholms sydvestkyst og deres fauna. II. Turonet. Danmarks Geol. Unders. II. Raekke 31, 39 pp. [In Danish].

Ravn, J. P. J. 1921: Kridtaflejringerne paa Bornholms sydvestkyst og deres fauna. III. Senonet. IV. Kridtaflejringerne ved Stampe Aa. Danmarks Geol. Unders. II. Raekke 32, 52 pp. [In Danish].

Ravn, J. P. J. 1930: Nogle bemaerkninger om Bornholms kridtaflejringer. Geol. Fören. Stockh. Förh. 52, 279-283. [In Danjsh].

Ravn, J. P. J. 1946: Om Nyker-omraadets kridtaflejringer. Biol. Skr. Dan. Vid. Selsk. 4, 36 pp. [In Danish].

Redtenbacher, A. 1873: Die Cephalopodenfauna der Gosauschichten im den nordöstlichen Alpen. Abh. K. K. geol. Reichsanst. 5, 91-140, pls. 22-30.

Riedel, L. 1931: Zur Stratigraphie und Faciesbilding im Oberemscher und Untersenon am Südrande des Beckens von Münster. Jb. Preuss. geol. Landesanst. Bergakad. 51, 605713, pls. $72-79$.

Roemer, A. 1840-1841: Die Versteinerungen des norddeutschen Kreidegebirges. 145 pp., 16 pls. Hahn'schen Hofbuchhandlung Hannover. (1-48, pls. $1-7,1840 ; 49-145$, pls. 8-16, 1841).

Roemer, F. A. 1852: Die Kreidebildungen von Texas und ihre organischen Einschlüsse, 100 pp., 10 pls. Adolph Marcus: Bonn.

Rosenkrantz, A. 1945: Smaabidrag til Danmarks Geologi. 2. Nye ammonitfund i kridtformationen paa Bornholm. Bull. Geol. Soc. Denmark 10, 439-442. [In Danish].

Schlüter, C. 1867: Beitrag zur Kenntniss der jüngsten Ammoneen Norddeutschlands. 36 pp., 6 pls. A. Henry, Bonn.

Schlüter, C: 1871-1876: Die Cephalopoden der oberen deut-. schen Kreide. Palaeontographica 21, 1-24, pls. 1-8 (1871); $21,25-120$, pls. $9-35$ (1872); 24, 121-264, pls. $36-55$ (1876).

Schlüter, C. 1874: Über die Scaphiten der Insel Bornholm. Sitzungsberichte der niederrheinischen Gesellschaft für Natur und Heilkunde in Bonn, 23-27.

Scott, G. R. \& Cobban, W. A. 1964: Stratigraphy of the Niobrara Formation at Pueblo, Colorado. Prof. Pap. U.S. Geol. Surv. 454-L, L1-L30, 11 pls.

Solakius, N. \& Larson, K. 1985: Foraminifera and biostratigraphy of the Arnager Limestone, Bornholm, Denmark. Danmarks Geol. Unders. C5, 40 pp. 
Sowerby, J. 1813: The Mineralogy Conchology of Great Britain. 1, pls. 10-44. The author, London.

Spath, L. F. 1921: On Upper Cretaceous Ammonoidea from Pondoland. Ann. Durban Mus. 3, 39-56, pls. 6-7.

Spath, L. F. 1922: On the Senonian ammonite fauna of Pondoland. Trans. R. Soc. S. Afr. 10, 113-147, pls. 5-9.

Spath, L. F. 1926: On new ammonites from the English Chalk. Geol. Mag. 63, 77-83, table.

Spath, L. F. 1932: A monograph of the Ammonoidea of the Gault. Monogr. Palaeontogr. Soc. Part 9, 379-410.

Stoliczka, F. 1863-1866: The fossil cephalopoda of southern India. Ammonitidae with revision of the Nautilidae \&c. Mem. geol. Surv. India (1) Palaeont. indica 3, (1) 41-56, pls. 26-31 (1863); (2-5), 57-106, pls. 32-54 (1964); (6-9), $107-154$, pls. $55-80$ (1865); (10-13), 155-216, pls. $81-94$ (1866).

Stolley, E. 1897: Ueber die Gliederung des norddeutschen und baltischen Senon sowie die dasselbe characteriserenden Belemniten: Arch. Anthrop. Geol. Schlesw.-Holst. 2, 216302.

Stolley, E. 1916: Neue Beiträge zur Kenntnis der norddeutschen Oberen Kreide I-IV. II. Über einige leitende Ammoniten und Inoceramen des Untersenons. Jber. Nieder. sächs. Geol. Ver. 9, 89-95, pl. 5.

Stolley, E. 1930. Einige Bemerkungen über die Kreide Südskandinaviens. Geol. Fören. Stockh. Förh. 52, 157-190.

Strombeck, A. von. 1859: Beitrag zur Kenntniss der Pläners über der Westphalischen Steinkohlenformation. $Z$. $d t$. geol. Ges. 11, 27-77.

Summersberger, H. 1979: Eine obersantone Ammonitenfauna aus dem Becken von Gosau (Oberösterreich). Ann. Naturhistor. Mus. Wien, 82, 109-176, 15 pls.

Ulbrich, H. 1971: Mitteilungen zu Biostratigraphie des Santon und Campans des mittleren Teils der Subherzynen Kreidemulde. Freiberger Forschft., 267, 47-60, 5 pls.

Whiteaves, J. F. 1903: On some additional fossils from the
Vancouver Cretaceous, with a revised list of species therefrom. Geol. Surv. Canada Mesozoic Fossils 1, (5), $309-409$, pls. $40-51$.

Wiedmann, J. 1962: Ammoniten aus der Vascogotischen Kreide (Nordspanien). 1, Phylloceratina, Lytoceratina. Palaeontographica. 118A, 119-237, pls. 8-14.

Wiedmann, J. 1966: Stammesgeschichte und system den posttriadischen ammonoideen; ein überblick. Neues $J b$. Geol. Paläont. Abh. 125, 49-79, pls. 1-2; 127, 13-81, pls. 3-6.

Wolleman, A. 1906: Mortoniceras pseudotexanum aus dem Emscher Lüneburgs. Zenibl. Miner. Geol. Palaont A 1906 379

Wright, C. W. 1953: Notes on Cretaceous ammonites. 1, Scaphitidae. Ann. Mag. Nat. Hist. (12) 6, 473-476.

Wright, C. W. 1979: The ammonites of the English Chalk Rock (Upper Turonian). Bull. Br. Mus. nat. Hist. (Geol.) 31, 281-332, 7 pls.

Wright, C. W. \& Matsumoto, T. 1954: Some doubtful Cretaceous ammonite genera from Japan and Saghalien. Mem. Fac. Sci. Kyushu Univ. Ser. (D), Geol., 4, 107-134, pls. $7-8$.

Wright, C. W. \& Wright, E. V. 1951: A survey of the fossil Cephalopoda of the Chalk of Great Britain. Monogr. Palaeontogr. Soc. 1-40.

Yabe, H. 1904: Cretaceous Cephalopoda from the Hokkaido. Part II. J. Coll. Sci. imp. Univ. Tokyo 20, 1-45, pls. 1-6.

Yabe, H. 1910: Die Scaphiten aus der Oberkreide von Hokkaido. Beitr. Paläeont. Geol. Öst.-Ung. 23: 159-174. pl. 15.

Zittel, K. A. von, 1884: Handbuch der Palaeontologie, 1, Abt. 2; Lief 3, Cephalopoda, pp. 329-522. Munich \& Leipzig: R. Oldenbourg.

Zittel, K. A. von 1895: Grundüzge der Palaeontologie (Palaeozoologie). vii +972 pp. Munich and Leipzig: R. Oldenbourg. 